\title{
Review \\ The Role of the Immune System in IBD-Associated Colorectal Cancer: From Pro to Anti-Tumorigenic Mechanisms
}

\author{
Sofía Frigerio ${ }^{1,2}$, Dalia A. Lartey ${ }^{1,2}$, Geert R. D'Haens ${ }^{1}$ and Joep Grootjans ${ }^{1,2, *}$ \\ 1 Department of Gastroenterology and Hepatology, Amsterdam University Medical Centers, Location AMC, \\ 1105 AZ Amsterdam, The Netherlands; s.n.frigerio@amsterdamumc.nl (S.F.); \\ d.a.lartey@amsterdamumc.nl (D.A.L.); g.dhaens@amsterdamumc.nl (G.R.D.) \\ 2 Tytgat Institute for Liver and Intestinal Research, Amsterdam University Medical Centers, Location AMC, \\ 1105 AZ Amsterdam, The Netherlands \\ * Correspondence: j.grootjans@amsterdamumc.nl
}

Citation: Frigerio, S.; Lartey, D.A.; D'Haens, G.R.; Grootjans, J. The Role of the Immune System in IBD-

Associated Colorectal Cancer: From Pro to Anti-Tumorigenic Mechanisms. Int. J. Mol. Sci. 2021, 22, 12739. https://doi.org/10.3390/ ijms222312739

Academic Editor: Massimo Triggiani

Received: 7 October 2021

Accepted: 23 November 2021

Published: 25 November 2021

Publisher's Note: MDPI stays neutral with regard to jurisdictional claims in published maps and institutional affiliations.

Copyright: (c) 2021 by the authors. Licensee MDPI, Basel, Switzerland. This article is an open access article distributed under the terms and conditions of the Creative Commons Attribution (CC BY) license (https:// creativecommons.org/licenses/by/ $4.0 /)$.

\begin{abstract}
Patients with inflammatory bowel disease (IBD) have increased incidence of colorectal cancer (CRC). IBD-associated cancer follows a well-characterized sequence of intestinal epithelial changes, in which genetic mutations and molecular aberrations play a key role. IBD-associated cancer develops against a background of chronic inflammation and pro-inflammatory immune cells, and their products contribute to cancer development and progression. In recent years, the effect of the immunosuppressive microenvironment in cancer development and progression has gained more attention, mainly because of the unprecedented anti-tumor effects of immune checkpoint inhibitors in selected groups of patients. Even though IBD-associated cancer develops in the background of chronic inflammation which is associated with activation of endogenous anti-inflammatory or suppressive mechanisms, the potential role of an immunosuppressive microenvironment in these cancers is largely unknown. In this review, we outline the role of the immune system in promoting cancer development in chronic inflammatory diseases such as IBD, with a specific focus on the anti-inflammatory mechanisms and suppressive immune cells that may play a role in IBD-associated tumorigenesis.
\end{abstract}

Keywords: IBD; IBD-associated cancer; inflammation; immune system; immune cells; immunosurveillance; immunosuppression; colitis-associated cancer; colorectal cancer

\section{Introduction}

Ulcerative Colitis (UC) and Crohn's Disease (CD) are the two forms of inflammatory bowel disease (IBD), characterized by chronic inflammation of the digestive tract leading to diarrhea, rectal bleeding and abdominal pain. One of the most severe complications of IBD is the development of colorectal cancer (CRC). It is generally accepted that the continuous exposure of intestinal epithelial cells (IECs) to proinflammatory stimuli and excessive cell damage with increased IECs turnover results in both genetic and immunological alterations, making IBD patients prone to developing CRC [1-3]. Population-based evaluations estimate that UC increases the risk of developing CRC two to three-fold compared to the non-IBD population $[4,5]$ and patients with CD have also been reported to have increased $\mathrm{CRC}$ risk when compared to the general population [6,7]. The risk of developing CRC increases significantly after 10 years of IBD diagnosis and is higher in patients with continuous chronic intestinal inflammation, highlighting the crucial role of a prolonged inflamed environment in the pathogenesis of IBD-associated cancer [8-10]. Compared to sporadic CRC, IBD-associated cancer has worse overall survival rates. The reported differences in clinical features, disease pathogenesis and epidemiologic characteristics, which may be explained by differences in tumor biology, have recently been excellently reviewed [11].

IBD-associated tumorigenesis follows a multistep sequence of genetic and morphological alterations in the intestinal epithelium, from inflamed intestinal mucosa to dysplasia 
and finally carcinoma $[12,13]$. The genetic mutations that drive the progression from dysplasia to carcinoma in IBD-associated cancer have been extensively studied and include mutations in tumor suppressor genes (TP53 mutations) and in genes that regulate the cell cycle and cell proliferation such as KRAS and APC mutations (Figure 1). Surprisingly, there is very little difference in the genetic mutations that drive carcinogenesis among IBD-associated cancer and sporadic CRC [14,15].

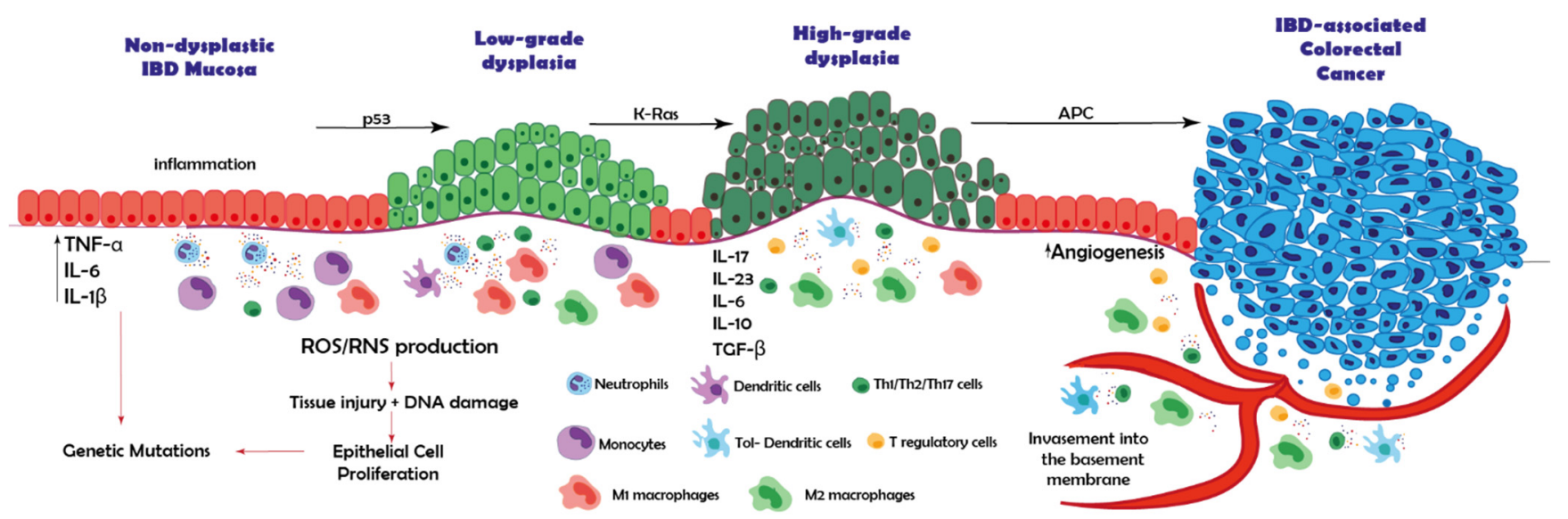

Figure 1. Schematic representation of the contribution of the immune system in the dysplasia to carcinoma sequence in IBD-associated cancer. Chronic inflammation promotes the recruitment of immune cells into the intestinal mucosa of inflammatory bowel disease (IBD) patients. These cells will secrete pro-inflammatory cytokines such as tumor necrosis factor alpha (TNF- $\alpha$ ), interleukin (IL) - 6 and IL-1 $\beta$. In addition, these tissue-infiltrating cells produce oxidative compounds including reactive oxygen species and reactive nitrogen species, generating tissue injury and DNA damage, promoting excessive epithelial cell proliferation and favoring genomic aberrations and genetic mutations. TP53 mutations result in low-grade dysplastic mucosa, after which mutations in KRAS are considered to be involved in progression from low-grade dysplasia to high-grade dysplasia. Finally, mutations in the APC gene result in cancer. Chronic inflammation also induces immunosuppressive mechanisms that may be involved in cancer progression, such as recruitment of M2 macrophages, $\mathrm{T}$ regulatory cells (Tregs) or T lymphocytes expressing inhibitory markers; programmed cell death protein 1 (PD-1), cytotoxic T-lymphocyte-associated protein 4 (CTLA-4). In addition, there is an increase in angiogenic factors and anti-inflammatory cytokines; IL-10 and transforming growth factor beta (TGF- $\beta$ ) which favor carcinoma development. (Tol-Dendritic cells: Tolerogenic dendritic cells, ROS: reactive oxygen species, RNS: reactive nitrogen species).

As IBD-associated dysplasia develops in the background of chronic inflammation, studies have highlighted the role of pro-inflammatory cytokines on tumorigenesis. Most observations were made in mouse models [16-20]. Little is known about the potential role of endogenous anti-inflammatory or immunosuppressive mechanisms that evolve as a consequence of chronic inflammation in the gastrointestinal tract, although such immunosuppressive mechanisms may contribute to tumorigenesis by impairing antitumor immunity.

This review will delineate the role of the immune system in IBD-associated cancer with a particular focus on the role of immunosuppressive mechanisms that may be involved in the development of CRC in IBD patients.

\section{IBD-Associated Cancer: From Inflamed Tissue to Carcinoma}

IBD patients are at higher risk of developing CRC, with disease extent and duration being two of the most prominent risk factors. For example, the risk of CRC in UC patients is 1,2 and $18 \%$ after 10,20 and 30 years of diagnosis, respectively $[9,21,22]$. However, recent evidence suggests that this risk is decreasing. In fact, an Australian cohort study performed in 2014 showed a cumulative risk of $1 \%$ at 10 years, $2 \%$ at 20 years and $3 \%$ at 30 years post diagnosis [23]. Patients with $\mathrm{CD}$ also appear to have an increased risk of CRC, similar to UC patients, yet this is only the case in those CD patients having colonic inflammation, and not in $\mathrm{CD}$ patients in which inflammation is confined to the 
small intestine [24]. This again emphasizes the critical role of chronic inflammation in the pathogenesis of IBD-associated cancer. Another very important risk factor for CRC in IBD patients is concomitant primary sclerosing cholangitis (PSC), which increases the CRC risk by at least 4 -fold when compared to UC patients without PSC [25]. The elevated risk of cancer in patients with IBD is also the consequence of the so-called field cancerization effect. In this phenomenon, clonally derived, neoplastic mutant cells form an indistinguishable "field" within the inflamed intestinal segment, meaning that the whole intestinal area is at risk of developing cancer [26].

IBD-associated cancer develops from dysplastic lesions within the colonic mucosa. Colorectal dysplasia can be defined as a neoplastic alteration of the intestinal epithelium that remains confined within the basal membrane [27]. Dysplastic lesions show specific morphological features, such as nuclear alterations, cytoplasmic abnormalities and an abnormal architectural pattern due to uncontrolled cell proliferation [28,29]. In IBD-associated cancer, there is a multi-step sequence of histological and morphological changes, namely from inflamed mucosa to low-grade dysplasia (LGD), high-grade dysplasia (HGD) and eventually carcinoma (Figure 1) [30]. This sequence is different from that in sporadic CRC, where an early adenoma-like lesion emerges from the normal mucosa, after which it evolves to late adenoma and finally adenocarcinoma [31].

Regarding the clinical aspects, CRC associated with IBD is often diagnosed at a more advanced stage compared to sporadic CRC. This is probably due to the difficulty in identifying dysplastic lesions in IBD-associated cancer, as they are usually flat and endoscopically unresectable $[1,9,26,32]$. The predominance of flat and unresectable lesions is one of the contributing factors to the increased mortality that this cancer presents, with a 1.7-fold increase in mortality among IBD-associated cancer patients in contrast with patients with non IBD and CRC [33]. After detection of LGD in IBD patients, guidelines recommend an intensified surveillance program or even a total colectomy due to high risk of developing cancer $[30,33]$. As an example, a recent study in a large IBD cohort with a history of LGD found a cumulative incidence of advanced neoplasia of $22 \%$ up to 15 years after LGD detection [34]. Moreover, around 25\% of all HGD and carcinoma lesions were detected within the first year after LGD detection [34], further emphasizing the risk of cancer progression in patients with IBD-associated dysplasia.

Given the unquestionable role of intestinal inflammation in IBD-associated cancer development, an optimal control of inflammation in IBD patients should prevent cancer development. The use of anti-inflammatory drugs that induce mucosal healing, together with appropriate endoscopic surveillance is considered the optimal strategy to prevent cancer development [35-37].

Although there is limited evidence of the direct protective effect of most of the biological therapies on the development of inflammation-induced cancer, a recent meta-analysis demonstrated that the use of 5-aminosalisylate (5-ASA) and thiopurines are protective factors for IBD-associated advanced neoplasia [33].

5-ASA is the most extensively used drug as maintenance therapy in UC [38,39]. Interestingly, mouse studies demonstrated that this drug reduced tumor growth in CAC mouse models, but not in sporadic CRC mouse models [40]. 5-ASA reduces tumor growth by affecting multiple molecular pathways. For instance, it reduces beta-catenin accumulation in APC-mutated cells and improves replication fidelity by reducing the occurrence of DNA mutations [41,42]. Meta-analyses regarding the protective effect of 5-ASA on CRC development showed conflicting results, probably due to heterogeneity in the populations studied. Moreover, it remains unclear whether it has an intrinsic protective effect, or whether protection is related to improved mucosal healing $[43,44]$.

Thiopurines have also been suggested as chemo-preventive agents in IBD-associated cancer $[45,46]$, although studies have shown conflicting results, likely again due to high heterogeneity in the studied cohorts and potential confounding factors. For example, no protection against $\mathrm{CAC}$ was observed with the use of thiopurines in the French CESAME 
cohort [47]. In contrast, a recent meta-analysis demonstrated a protective role of thiopurines in CAC prevention among UC patients with HGD [48].

Taken together, IBD-associated cancer represents a relevant clinical problem, which is reflected in its high mortality rate and the difficulty of early detection, diagnosis and treatment. In order to improve clinical management and to better predict which patients are more likely to develop carcinomas from dysplastic lesions, it is critical that we understand the pathophysiology of IBD-associated dysplasia and cancer.

\section{The Role of the Immune System in Cancers Developing on the Background of Chronic Inflammation}

Chronic inflammation results in continuous tissue damage, accumulation of immune cells and fibrosis. This dysregulated and chronically inflamed environment can be observed in the setting of many autoimmune disorders with recurrent episodes of acute inflammation, and in patients with long-standing chronic infections [49]. It is well established that such a chronically inflamed environment is associated with the development of cancer, as approximately $25 \%$ of cancers develop in the background of such chronic inflammation and/or chronic infection [50-52]. For example, Helicobacter pylori gastritis is associated with gastric cancer [53-55], human papillomavirus infection with cervical cancers [56,57], and chronic hepatitis B and C infection is associated with hepatocellular carcinoma [58,59]. In addition to microbial-induced inflammation, inflammatory autoimmune conditions, including IBD and PSC, are associated with the development of CRC and cholangiocarcinoma, respectively $[9,11,13,21,60,61]$.

The current consensus is that chronic inflammatory conditions lead to genetic mutations, genomic instability and DNA damage, as well as to immune cell dysregulation, which collectively promotes cancer development [1,3,62-64]. Indeed, many pro-inflammatory mediators that are present in a chronically inflamed environment can drive neoplastic transformation, such as cytokines interleukin (IL) -1 $\beta$, IL-6, Tumor Necrosis Factor alpha (TNF- $\alpha$ ) [65-68], other molecules and transcription factors (prostaglandin E2, S100A8/9 proteins, STAT3-mediated signaling) [69-77], as well as chemokines: C-C motif ligand (CCL) -2, CCL5, CCL22, C-X-C motif ligand (CXCL) -5, CXCL12 [78-80]. In particular, CXCL12 secreted by stromal fibroblasts can bind to its receptor in tumor cells and stimulate motility and chemotaxis [81]. In addition, it has been demonstrated that neutralizing antibodies against CCL2 and CXCL8 prevent the formation of lung metastases and inhibit tumor growth in breast carcinoma and prostatic cancer mouse models, respectively, demonstrating their pro-tumorigenic role [82,83].

However, apart from pro-inflammatory mediators, endogenous anti-inflammatory mechanisms that evolve during chronic inflammation may also shape an environment in which cancer cells thrive (Figure 2). Unbalanced immune and non-immune secreted compounds may result in a shift to an immunosuppressive microenvironment, affecting the immune system's ability to eliminate neoplastic cells. Thus, a chronic pro-inflammatory environment may not only be associated with cancer formation through continuous tissue damage and presence of pro-inflammatory tumor-driving mediators, but also through a chronic inflammation-induced immunosuppressive state, which interferes with the generation of effective anti-tumor immune responses.

First, tissue-infiltrating monocytes and tissue-resident macrophages display a shift towards an anti-inflammatory M2 phenotype under chronic inflammatory conditions [84,85]. These cells elicit several suppressive functions, including impairment of effector activity of T cells and dendritic cells (DCs) by anti-inflammatory cytokine production [86-88]. In addition, M2-like macrophages stimulate cell proliferation via epidermal growth factor production and angiogenesis, which facilitates tumor invasion [89-91]. In addition, chronic inflammation leads to the recruitment of myeloid-derived suppressor cells (MDSCs) (Figure 2), immature immune cells specialized in suppressing $\mathrm{T}$ cell effector functions and proliferation [92]. MDSCs also produce anti-inflammatory cytokines and reduce expression of activation markers on natural killer (NK) cells [93], all of which lead to a defect in immunosurveillance and promote cancer development. 


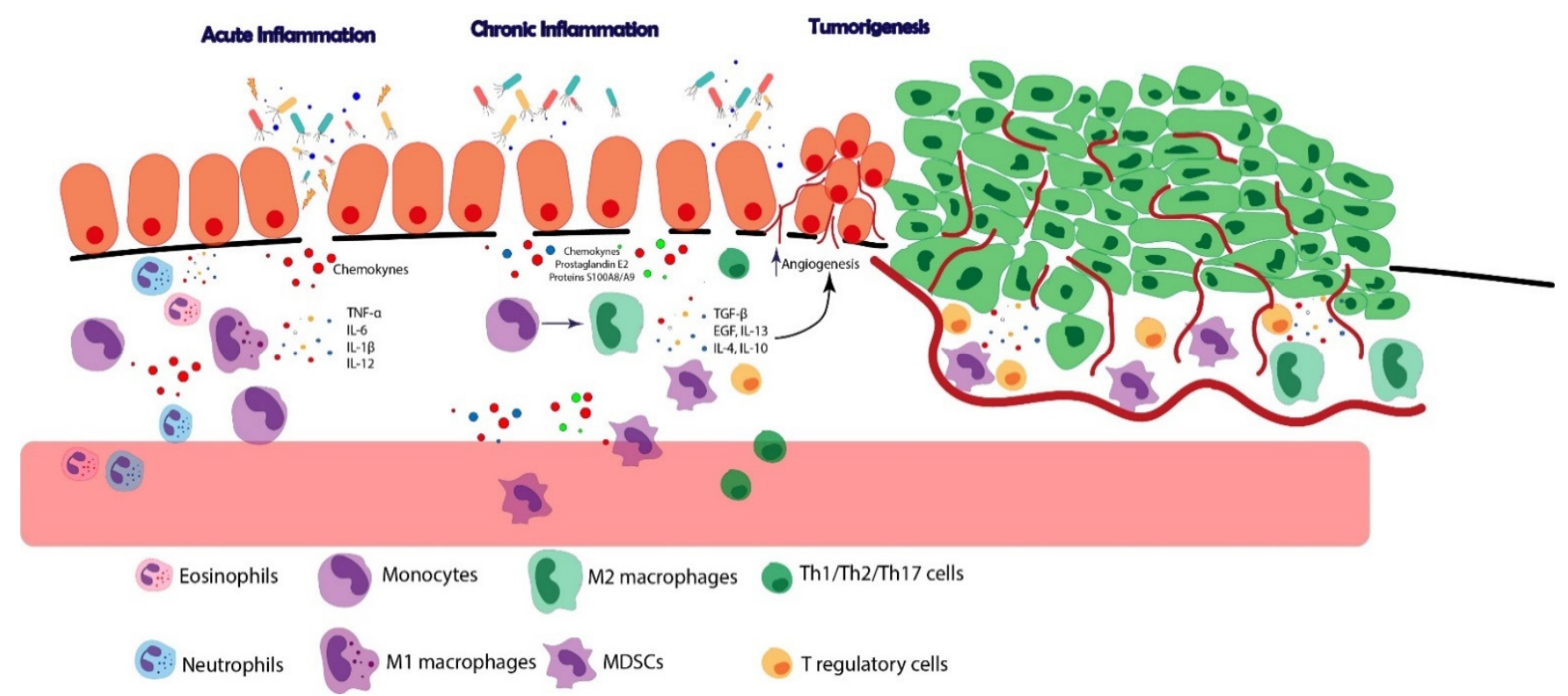

Figure 2. Schematic representation of chronic inflammation-associated carcinogenesis. Tissue injury, microbial infections or autoimmune diseases trigger acute inflammatory responses, characterized by an abundance of neutrophils, eosinophils and monocytes, which are recruited into the tissue by a variety of chemokines. Together with M1 macrophages these immune cells produce pro-inflammatory cytokines (TNF- $\alpha$, IL-6, IL-1 $\beta$, IL-12) leading to tissue damage. When inflammation becomes chronic, adaptation occurs with a shift towards increased numbers of macrophages and lymphocytes among tissueinfiltrating cells, and alteration of the inflammatory milieu with other inflammatory compounds such as prostaglandin E2 and S100A8/9 proteins. In addition, immune-regulatory and anti-inflammatory mechanisms emerge, which may promote carcinoma development, such as increased M2 macrophage differentiation from monocytes, and recruitment of immunosuppressive cells; myeloid-derived suppressor cells (MDSCs) and Tregs. M2 macrophages produce antiinflammatory cytokines (TGF- $\beta$, EGF, IL-13, IL-10) which can, for example, promote angiogenesis and fibrosis, favoring tumor growth. Consequently, the tumor itself creates an immunosuppressive milieu, characterized by elevated levels of M2 macrophages, MDSCs and Tregs. (EGF: epidermal growth factor).

Second, mounting proper immune responses against dysplastic/tumor cells requires recognition of tumoral antigens by DCs, which then prime naive T cells in secondary lymphoid organs. In chronically inflamed tissues, however, this crucial DC function may be impaired as a consequence of an increase in tolerogenic DCs with a low capacity of antigen presentation and decreased class-II major histocompatibility complex expression [94], which is associated with defective antigen presentation to naive $\mathrm{T}$ cells and thus impaired $\mathrm{T}$ cell anti-tumor immunity. This is critical, as $\mathrm{T}$ cells are the most important orchestrators of the anti-cancer immune response, both through direct tumoral cell killing by cytotoxic $\mathrm{T} \mathrm{CD}^{+}$cells, and through activation of anti-tumor immune responses with the help of $\mathrm{T}$ $\mathrm{CD} 4^{+}$helper cells type 1 (Th1) [95].

Next to this impaired function of $\mathrm{T}$ cells, chronic inflammation leads to regulatory T cells (Tregs) recruitment [96] (Figure 2). Tregs are immunosuppressive in that they impair the function of T, NK and DC cells by producing anti-inflammatory cytokines (IL-10, transforming growth factor beta (TGF- $\beta$ )). In addition, they express inhibitory surface markers that facilitate immune-cell suppression, such as programmed cell death protein 1 (PD-1) and cytotoxic T-lymphocyte-associated protein 4 (CTLA-4), among other suppressor mechanisms [97-99]. These inhibitory markers can also be induced by pro-inflammatory cytokines and mediators that can be found in a chronic inflamed milieu. For example, interferon-gamma (IFN- $\gamma$ ) can stimulate expression of programmed death-ligand 1 (PD-L1) in lung and colon cancer cell lines [100,101]. Moreover, chronic inflammatory conditions induce PD- 1 and the inhibitory marker CTLA- 4 in $\mathrm{CD}^{+}, \mathrm{CD}^{+} \mathrm{T}$ cells and Treg cells in chronic infections due to continuous antigen stimulation [102,103], and negatively regulate T cell activation [104]. Although expression of these inhibitory cell surface proteins is 
likely involved in controlling excessive inflammation, their possible role in promoting carcinogenesis in a chronically inflamed tissue is unclear.

In summary, chronic inflammatory diseases predispose individuals to an increased risk of cancer by chronic tissue damage, DNA damage and several pro-inflammatory cytokines, but likely also by generating a tumor-promoting anti-inflammatory and suppressive microenvironment.

\section{The Role of the Immune System in IBD-Associated Cancer}

4.1. Immune Signaling Pathways in IBD: Contribution to Cancer Onset

4.1.1. NF- $\mathrm{KB} / \mathrm{TNF}-\alpha$

$\mathrm{NF}-\mathrm{kB}$ is a family of transcription factors which play a role in inflammation, cell proliferation and malignant transformation [105]. In both canonical and non-canonical pathways, NF- $\mathrm{kB}$ forms a complex with its inhibitor IкB in the cytoplasm. In response to diverse stimuli such as inflammatory cytokines, growth factors or microbial components, I $\mathrm{KB}$ is degraded by IкB kinase (IKK complex) and NF- $\mathrm{KB}$ is translocated into the cell nucleus as part of the canonical pathway [106]. Once in the nucleus, it regulates the transcription of pro-inflammatory cytokines, chemokines and other inflammatory mediators that will promote and sustain the inflammatory reaction. As a pivotal regulator of the inflammatory responses, NF- $\mathrm{kB}$ has been implicated in the pathogenesis of IBD [107]. Furthermore, it has been shown that NF- $\mathrm{kB}$ contributes to IBD-associated tumorigenesis, mainly by activating the transcription of pro-inflammatory cytokines and by promoting tumor growth and metastasis via promotion of angiogenesis-related genes and anti-apoptotic genes [108,109] (Figure 3). The crucial role of NF- $\mathrm{KB}$ in IBD-associated cancer development has been demonstrated in vivo in a mouse colitis-associated cancer (CAC) model; Azoxymethane $(\mathrm{AOM})$ /dextran sulfate sodium (DSS) model, in which inactivation of the canonical NF$\mathrm{kB}$ signaling pathway through specific ablation of NF- $\mathrm{KB}$ kinase $\mathrm{B}(\mathrm{IKK} \beta)$ in intestinal epithelial cells reduced tumor incidence. Interestingly, deletion of the gene encoding IKK $\beta$ in myeloid cells decreased both tumor number and size, demonstrating the importance of NF-KB signaling in immune cells in CAC development [110]. In another study in AOM/DSS-treated mice, deletion of NLRP12, a member of the Nod-like receptor family which negatively regulates NF- $\mathrm{kB}$, resulted in severe colitis and increased susceptibility to CAC as compared to wild-type mice [111]. This further demonstrates the important pro-tumorigenic role of NF- $\mathrm{KB}$ in IBD and IBD-associated cancer by limiting apoptosis and by promoting the production of pro-inflammatory cytokines.

Moreover, NF- $\mathrm{kB}$ is a transcription factor for many pro-inflammatory cytokines, such as TNF- $\alpha$, a pleiotropic cytokine that promotes IECs apoptosis and acts on innate immune cells via activation of the NF- $\mathrm{kB}$ transcription pathway, among other important functions $[112,113]$. TNF- $\alpha$ seems to play a controversial role in cancer progression in IBD. It can induce epigenetic changes and can promote oncogene expression levels [114]. The pro-tumorigenic role of TNF- $\alpha$ in the progression to cancer under chronic inflammatory conditions was demonstrated in CAC mouse models, in which treatment with anti-TNF- $\alpha$ antibodies decreased both inflammation and the number of intestinal carcinomas [16]. Furthermore, administration of a transmembrane TNF- $\alpha$ antibody in an AOM/DSS mouse model dampened the inflammatory response and tumor formation. Anti-tumorigenic effects were observed both during the inflammation induction cycles with DSS and after CAC development, highlighting transmembrane TNF- $\alpha$ as a candidate target for treatment [115]. Unfortunately, there are currently no human data available that demonstrate a clear effect of anti-TNF antibodies in protection from IBD-associated cancer [116]. However, two cohort studies with long-term follow-up of IBD patients treated with the anti-TNF- $\alpha$ antibody infliximab, did not show increased CRC incidence $[117,118]$. 

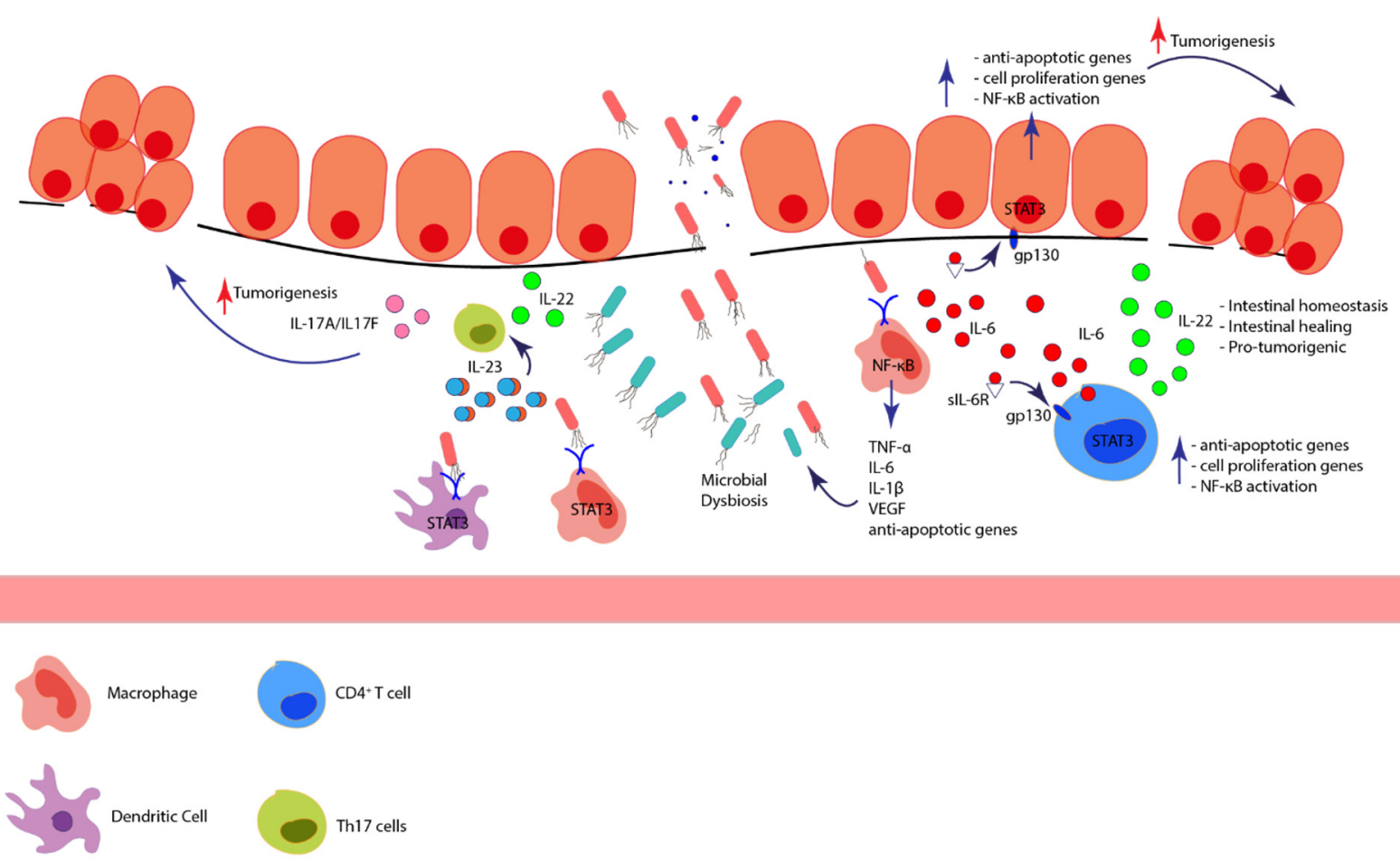

Figure 3. Pro-inflammatory immune signaling pathways in IBD and their contribution to IBD-associated cancer. Disruption of the intestinal epithelial layer causes the entry of luminal microorganisms. Pathogen-specific structures are recognized in the intestinal mucosa via Toll-like receptors by innate immune cells, activating the transcription factor NF- $\mathrm{B}$ and promoting TNF- $\alpha$, IL-6 and IL-1 $\beta$ production. NF- $\mathrm{kB}$ also stimulates transcription of vascular endothelial growth factor and a number of anti-apoptotic genes, enhancing angiogenesis, cell survival and proliferation. IL-6 has a potent pro-tumorigenic effect, mainly via STAT3 signaling. It binds to soluble or membrane-bound receptors which interact with gp130 either in intestinal epithelial cells or immune cells, triggering the activation of signaling molecules and transcription factors, including STAT3. STAT3 regulates the transcription of genes related to cell proliferation and survival and stimulates activation of NF- $\mathrm{kB}$, creating a positive feedback loop. It also stimulates production of IL-22 by CD4 ${ }^{+} \mathrm{T}$ cells, which is important in intestinal homeostasis but potentially also facilitates carcinogenesis. Microbial recognition by antigen presenting cells also stimulates production of IL-23 via STAT3 signaling, leading to Th17 polarization with the subsequent production if IL-17A, IL-17F and IL-22, cytokines associated with carcinogenesis. (TLRs: toll-like receptor, VEGF: vascular endothelial growth factor).

\subsubsection{IL-6/STAT3 and IL-22/STAT3}

IL-6 is produced by innate immune cells residing in the intestinal mucosa and regulates survival and proliferation of IECs [119]. Importantly, IL-6 has been demonstrated to have a strong impact on the early progression to carcinoma in IBD via STAT3 signaling (Figure 3). Increased expression of IL-6 and STAT3 was demonstrated in biopsies from UC patients with active disease and in IBD-associated carcinomas, as compared to patients with inactive disease or controls [120]. In CAC mouse models, IL-6 ablation reduced tumor formation and mice injected with recombinant IL-6 had increased tumor load. This was STAT3dependent, as deletion of STAT3 specifically in IECs resulted in lower tumor numbers and size, as well as a reduced percentage of proliferating cells in colonic crypts [121]. Further research into the possible mechanism of IL-6-mediated tumor promotion showed that macrophage-derived IL-6 attached to a soluble IL-6R is crucial in IL-6 trans-signaling in intestinal epithelial cells and thus in the development of CAC [20]. Thus, several studies have shown that IL-6, and downstream STAT3 signaling, is a critical tumor-promoting cytokine in CAC.

STAT3 may also be indirectly involved in CAC via activation of IL-22 production, for example by $\mathrm{CD}^{+} \mathrm{T}$ cells [122]. IL-22 is an important cytokine for epithelial cell and mucus layer regeneration, as well as for the production of antimicrobial compounds and mucosal wound healing $[123,124]$ (Figure 3). However, despite its role in intestinal homeostasis, 
IL-22 may also possess pro-tumorigenic effects, as increased expression of IL-22, IL-22R and phosphorylated STAT3 have been demonstrated in inflamed and dysplastic intestinal tissues from UC patients [125,126].

\subsubsection{NFAT}

NFAT is a family of transcription factors mainly expressed in T cells, which regulate important activating signaling pathways. NFAT has been shown to be involved in both IBD pathogenesis and CRC development [127-129] and has therefore also been studied in CAC development. In a CAC mouse model, NFATc2-deficiency resulted in decreased tumorigenesis, which was accompanied by reduced intestinal inflammation and decreased production of the pro-inflammatory cytokines IL- 6 and IL- 21 by CD4 ${ }^{+} \mathrm{T}$ cells in spleen and lamina propria. Furthermore, the administration of hyper IL- 6 abrogated the effect of protection in NFATc2-KO mice [130]. This shows that NFATc2 promotes tumorigenesis in the context of colitis, in a process dependent on IL-6. Apart from NFATc-2, NFATc-3 has been shown to be upregulated in AOM/DSS-treated CAC mice as compared to control mice. Mice deficient in NFATc3 showed a decrease in tumor numbers and size. In addition, NFATc3 inhibited proliferation and epithelial to mesenchymal transition in vitro in a CRC cell line [131]. In conclusion, NFATc2 and NFATc3 are key regulators of intestinal inflammation and are important in the initiation and progression of IBD-associated cancer.

\subsubsection{IL23/STAT3/Th17 Signaling Pathway}

IL-23 is produced by a variety of immune cells, including antigen presenting cells (APCs), and plays an important role in sustaining the inflammatory response in IBD [132,133]. The IL-23 heterodimer is made up of the p19 and the p40 subunit. Once IL-23 binds to its receptor IL-23R, it activates janus kinases, which will then phosphorylate the receptor, inducing the recruitment of several STAT proteins, including STAT3. Ultimately, IL-23 signaling activates the transcription of effector cytokines genes belonging to the Th17 subtype, such as IL-17A, IL-17F, IL-22 and IFN- $\gamma$ [134] (Figure 3). The role of the IL23/Th17 pathway in CAC pathogenesis is not completely clear, but IL-17A appears to drive tumor formation in mouse models for inflammation-induced cancer, as both a blockade of IL-17A by anti-IL-17A antibodies [135], and genetic deletion of IL-17A [136] was associated with decreased tumor size and number.

According to the pro-tumorigenic role of the IL-23/Th17 signaling pathway, it could be envisioned that treating IBD patients with anti-IL-23 or anti-IL-17A antibodies would also contribute to a decrease in CAC incidence, both indirectly by decreasing inflammation, but potentially also directly. Ustekinumab, a humanized monoclonal antibody that binds to the p40 subunit, is currently used for the treatment of UC [137]. Even though clinical data are still lacking, preliminary results in a mouse preclinical model identified IL-23 as a promising target to prevent CRC associated with chronic inflammation in IBD [138]. One of the important effects of the use of ustekinumab that needs to be considered as a risk factor for CRC is that blocking p40 is also associated with decreased levels of antitumorigenic IL-12 [139,140]. Fortunately, randomized clinical trials reported very low incidence of colorectal cancer patients receiving Ustekinumab as compared to patients receiving placebo, even though the follow-up period was short (52 weeks) [141], and long-term safety data for its use in UC patients will follow.

\subsection{Immune Cells in IBD and Its Contribution to IBD-Associated Cancer}

In this section, we will comment on the role of immune cells in immunosurveillance against cancer and IBD-associated cancer, and on the pro- and anti-inflammatory mechanisms that these cells possess to promote cancer development in the chronic inflamed IBD environment. 


\subsubsection{Macrophages}

Macrophages, mainly tissue-resident cells belonging to the innate immune system, are involved in both anti-inflammatory (M2 or alternatively activated) as well as proinflammatory (M1 or classically activated) immune responses. In the intestine, monocytes change into tolerogenic lamina propria macrophages, which are hyporesponsive to microbial stimuli and do not initiate inflammatory responses [142]. In addition, these macrophages produce large amounts of anti-inflammatory cytokines, such as IL-10 and TGF- $\beta$, creating a tolerogenic environment and promoting the expansion of $\mathrm{CD} 44^{+} \mathrm{CD} 25^{+}$ Treg T cells [143]. Biopsies from IBD patients demonstrate a high abundance of monocytederived macrophages infiltrating the intestinal mucosa, predominantly of the M1 or proinflammatory phenotype [144-146]. More recently, it was shown that the non-dysplastic mucosa from IBD patients is populated by both M1 and M2 macrophages [147].

Classically, M1 macrophages participate in anti-tumor immunosurveillance by directly acting as APCs to activate T cells. In addition, macrophages produce cytokines that determine polarization to different effector T-cell subtypes and phagocytose neoplastic cells that are covered with antibodies and other opsonins [148]. In IBD, macrophages have also been proposed to actively play a role in tumorigenesis. M1 proinflammatory macrophages foster a pro tumorigenic environment by producing tumor-promoting cytokines, which exert a well-known proliferative effect on colonic cells via induction of transcription factor NF- $\mathrm{KB}$ and signal transducer STAT3 $[76,149]$. Macrophages have also been identified in IBDassociated dysplastic lesions and the level of macrophage infiltration correlated positively with the number of dysplastic lesions [150]. In line with these results, Khan and colleagues also identified a progressive increase in macrophage density from colitis to dysplasia and cancer [151]. Although the phenotype of these macrophages was not identified, another study showed that the percentage of M2-like macrophages markedly increased in IBDassociated cancers, suggesting a polarization to anti-inflammatory or immunosuppressive macrophages in the transition from dysplasia to carcinoma [152]. In support of this, Kvorjak et al. showed that $\mathrm{CD} 163^{+}$M2-like macrophages are significantly increased in intestinal tissue from UC- and IBD-associated cancer patients [153]. Moreover, the authors postulate that CCL17 and IL-13 produced by these CD163 ${ }^{+} \mathrm{M} 2$ macrophages induce activation of oncogenic pathways involving AKT and STAT6, as well as expression of aberrant glycans on colonic epithelial cells which inhibit activity of DCs and NK cells, thus dampening immunosurveillance (Table 1). Another intriguing anti-inflammatory mechanism by which macrophages may promote tumorigenesis is by the abolishment of $\mathrm{T}$ cell proliferation through nitric oxide production. More specifically, it was shown that macrophages that express inducible nitric oxide synthase (iNOS) were capable of suppressing antigen-specific T-cell responses against Listeria monocytogenes in the spleen [154] (Table 1). As iNOS+ macrophages are abundant in inflamed intestinal mucosa in IBD, it seems plausible that they also exert a suppressive effect in $\mathrm{T}$ cells, affecting immunosurveillance against the malignant transformed cells that appear in the pro-tumorigenic, inflamed milieu. It has also been proposed that macrophages may have a dichotomous effect in IBD-associated cancer via TGF- $\beta$ activation by the nuclear receptor PPAR- $\gamma$. In particular, linoleic acid, a chemical compound present in the diet, activates PPAR- $\gamma$, which stimulates macrophages to produce TGF- $\beta$, ameliorating colitis symptoms but increasing tumorigenesis in a CAC mouse model [155].

In conclusion, macrophages display both pro- and anti-inflammatory mechanisms that contribute to IBD-associated cancer. It could be envisioned that M1 macrophages initially invade IBD-inflamed mucosa and are involved in carcinogenesis by the production of pro-inflammatory mediators. M1-like macrophages acquire a more M2-like immunosuppressive phenotype as inflammation becomes chronic, and indeed a higher abundance of M2 macrophages with anti-inflammatory properties is observed in dysplastic lesions and carcinomas in IBD (Figure 1). This could further accelerate carcinogenesis as their immunosuppressive phenotype hinders adequate immunosurveillance. To better characterize 
these mechanisms, more studies into the role of macrophages in IBD-associated cancer are necessary.

Table 1. Possible anti-inflammatory and immunosuppressive mechanisms that may dampen immunosurveillance during IBD-associated carcinogenesis.

\begin{tabular}{|c|c|}
\hline Immune Cell & Mechanism \\
\hline \multirow{4}{*}{ Macrophages } & $\begin{array}{l}\text { - Accumulation of } \mathrm{CD} 163^{+} \mathrm{M} 2 \text { macrophages that activate oncogenic pathways via IL-13 and } \\
\text { CCL17 in UC and CAC patients [153]. }\end{array}$ \\
\hline & $\begin{array}{l}\text { - Glycan-induced expression on colonic epithelial cells by } \mathrm{CD} 163^{+} \mathrm{M} 2 \text { macrophages that } \\
\text { inhibit NK and DC function in UC and CAC patients [153]. }\end{array}$ \\
\hline & - Inhibition of T-cell responses via iNOS ${ }^{+}$macrophages [154]. \\
\hline & - $\quad$ TGF- $\beta$ production by PPAR- $\gamma$ expressing macrophages [155]. \\
\hline \multirow{2}{*}{ Dendritic Cells (DCs) } & $\begin{array}{l}\text { - Notch-2- DCs with less migration to MLNs and antigen presentation capacity to CD8 }{ }^{+} \mathrm{T} \\
\text { cells [156]. }\end{array}$ \\
\hline & $\begin{array}{l}\text { - Plasmacytoid dendritic cells (pDCs) induce recruitment of MDSCs into intestinal mucosa in } \\
\text { a CAC mouse model [157]. }\end{array}$ \\
\hline $\begin{array}{l}\text { Myeloid-derived suppressor } \\
\text { cells (MDSCs) }\end{array}$ & CXCR2-expressing MDSCs in mice colonic mucosa inhibit CD8 ${ }^{+} \mathrm{T}$ effector functions [158]. \\
\hline \multirow{3}{*}{ T cells } & $\begin{array}{l}\text { - Increased expression of inhibitory markers (PD-1, CTLA-4, PD-L1) in CD8 }{ }^{+} \mathrm{T} \text { cells in } \\
\text { IBD-associated cancer tumors and intestinal epithelium from CAC mice }[159,160] .\end{array}$ \\
\hline & Decreased granzyme B expression in $\mathrm{CD}^{+} \mathrm{T}$ cells in IBD-associated cancer patients [161]. \\
\hline & $\begin{array}{l}\text { - Tregs suppress CD } 8^{+} \mathrm{IFN}-\gamma^{+} \mathrm{T} \text { cells producers of granzyme B in a CAC mouse } \\
\text { model }[162,163] .\end{array}$ \\
\hline Natural Killer (NK) cells & $\begin{array}{l}\text { - Limited killing capacity and mitochondrial activity of circulating NK cells from IBD } \\
\text { patients [164]. }\end{array}$ \\
\hline
\end{tabular}

\subsubsection{Neutrophils and Eosinophils}

Apart from monocyte-derived macrophages, other polymorphonuclear cells such as neutrophils and eosinophils are recruited into the inflamed mucosa in IBD [165,166], but their role in promoting IBD-associated cancer has not yet been well addressed. Interestingly, expression of the transcription factor BATF3 in intestinal epithelial cells promoted the transcription of CXCL5, which together with CXC chemokine receptor (CXCR)- 2 stimulate neutrophil recruitment, which was associated with increased CAC development in AOM/DSS-treated mice [167]. Neutrophils have a prominent place in IBD pathophysiology, being a central effector cell in inducing mucosal damage, producing reactive oxygen species, reactive nitrogen species and other specific enzymes that disrupt intestinal tissue [168]. This can also promote dysplasia and carcinoma development in the context of IBD, as neutrophil-derived products generate DNA damage and genetic mutations and result in increased epithelial cell proliferation [169]. Conversely, some studies show that neutrophils contribute to immunosurveillance, and have a protective role in the development of IBD-associated cancer. For example, Zhou et al. reported the presence of a subpopulation of neutrophils, namely $\mathrm{CD} 177^{+}$neutrophils, that have tumor-suppressor properties. These neutrophils suppressed tumorigenesis and epithelial proliferation demonstrated by increased expression of the proliferation marker Ki67 in $\mathrm{CD} 177^{-/-}$mice. In line with this, patients with IBD-associated cancer and CRC patients with high $C D 177^{+}$neutrophil infiltration had better overall survival compared to the control population [170]. Another study recently showed that neutrophils slow tumor growth by restricting tumor-associated microbiota and IL-17-dependent tumor-associated inflammatory responses [171]. Thus, neutrophils have a dual role in IBD-associated carcinogenesis, being both pro-tumorigenic by generating pro-inflammatory mediators that increase DNA damage and tissue turnover, and anti-tumorigenic by playing an important role in immunosurveillance.

Together with neutrophil infiltration, eosinophils are also commonly present in the inflamed mucosa of IBD patients [172,173]. Activated eosinophils accumulate in the gut of IBD patients and directly contribute to the onset of the inflammatory process in 
IBD by degranulation [174]. In general, the presence of eosinophils in tumors correlates with a better disease outcome $[175,176]$, and the presence of activated eosinophils has been demonstrated to reduce tumor growth in CRC [177,178]. In IBD-associated cancer, eosinophils seem to play a protective role in tumor development mainly via the effect of the cytokine IL-33. Specifically, IL-33 has been demonstrated to sustain eosinophils by increasing their viability and cytotoxic potentials, making them more effective at fighting malignant cells [179]. However, additional studies are necessary to unravel the function of eosinophils in IBD-associated cancer.

\subsubsection{Dendritic Cells}

DCs are a heterogeneous group of APCs specialized in the recognition and processing of antigens, and in the activation of naive T lymphocytes. In homeostasis, DCs promote and maintain a tolerogenic immune response. Conversely, in IBD, DCs lose their tolerogenic phenotype and display pro-inflammatory features, causing excessive T-cell responses with the subsequent overload of pro-inflammatory cytokines [180-183]. This pro-inflammatory milieu may drive cancer formation, yet the subsequent $\mathrm{T}$ cell responses also play a key role in cancer immunosurveillance.

Only few studies exist that highlight a specific anti-tumoral function of DCs in IBDassociated cancer. In a mouse model for CAC, IRF8-expressing cDC1s (conventional DCs specialized in activating $\mathrm{T} \mathrm{CD}^{+}$cells) do not seem to contribute to anti-cancer immune responses [184]. Furthermore, it was shown that alterations in phenotype and function of DCs in IBD could play a role in the onset of IBD-associated cancer. First, it was demonstrated that DCs foster a pro-neoplastic inflammatory environment through expression of the transcription factor T-bet [185]. Additionally, it was demonstrated that DCs may exert anti-inflammatory or immunosuppressive mechanisms in the non-dysplastic mucosa from IBD patients, dampening immunosurveillance and contributing to carcinoma progression. For example, it was recently shown that malignant transformation of dysplastic lesions was accelerated in CAC mice in which the transcription factor Notch 2 was deleted in DCs. The authors further demonstrated that Notch2-deficient DCs displayed differentiation defects and had less CC chemokine receptor (CCR)-7 expression, which impeded the migration to the mesenteric lymph nodes and abolished adequate antigen cross-presentation to CD8 ${ }^{+}$ T cells (Table 1). This may therefore impact immunosurveillance and favor the dysplasia to carcinoma progression in mice [156]. Interestingly, pDCs could also play a role in the development of IBD-associated cancer through the recruitment of MDSCs, as observed in a mouse model for CAC [157] (Table 1). These MDSCs are known for their suppressor capacity, are increased in several malignancies and have been implicated in tumorigenesis $[186,187]$. Thus, increased pDCs in IBD are involved in shaping a pro-tumorigenic milieu by recruitment of immunosuppressive cells, including MDSCs. CXCR2-expressing MDSCs are also recruited into the colonic mucosa of AOM/DSS-treated mice, which resulted in inhibition of $\mathrm{CD}^{+} \mathrm{T}$ cell effector functions, thereby accelerating tumor growth [158].

Taken together, DCs in IBD-associated cancer may have an anti-inflammatory role, associated with suppressed immunosurveillance. However, it is noteworthy that most of our knowledge regarding the role of DCs in IBD-associated cancer relies on mouse models. Therefore, more insight into the role of DCs in inflammation-associated colorectal carcinogenesis in humans is necessary.

\subsubsection{T Cells}

The lamina propria intestinal T-cell compartment is mainly composed of effector memory $\mathrm{CD}^{+}$resident $\mathrm{T}$ cells [188]. They are categorized as $\mathrm{CD} 4^{+}$helper $\mathrm{T}$ cells (Th), which are further subdivided into Th1, Th2, Th17 and Treg cells (Figure 3). The first three subtypes are effector $T$ cells that act against intracellular pathogens (Th1), helminth parasites and other extracellular microbes (Th2) and extracellular bacteria and fungi (Th17) [189]. In addition, they actively participate in other non-infectious pathologies, such as allergies, autoimmune diseases or anti-tumor immune responses [189]. Conversely, Tregs are in 
charge of suppressing and controlling immune responses [190]. Although all these Th subtypes are present in the lamina propria, there is an enrichment of Foxp $3^{+}$Tregs and IL-17 producing Th17 cells in the lamina propria under homeostatic conditions [191]. In IBD, however, an imbalance of the homeostatic Th populations has been observed in the gut, with Th1-Th17/Th2 polarization of $\mathrm{T} \mathrm{CD} 4^{+}$cell immune responses being involved in IBD pathophysiology [192].

$\mathrm{T}$ cells play a crucial role in immunosurveillance; $\mathrm{CD} 8^{+} \mathrm{T}$ cells can directly eliminate neoplastic cells, and $\mathrm{CD}^{+} \mathrm{T}$ cells collaborate with macrophages, NK cells and $\mathrm{CD} 8^{+} \mathrm{T}$ cells to mount anti-tumor immune responses $[50,95,193]$. In IBD-associated cancer, possible immunosurveillance functions of $\mathrm{T}$ cells in dysplastic lesions were postulated, associated with the expression of the co-stimulatory molecule CD80. Specifically, it was demonstrated that inhibition of CD80 signaling in vivo in a CAC mouse model significantly increased the frequency and size of high-grade dysplastic lesions, whereas restoration of CD80 expression decreased colonic dysplasia [194]. Another T-cell related immunological interaction relates to the CD30/CD30L axis. CD30L is expressed on T CD4 ${ }^{+}$-activated cells [195]. Deletion of CD30L in an AOM/DSS-induced CAC mouse model promoted formation of an immunosuppressive tumor microenvironment, characterized by an increased percentage of PD-L1 ${ }^{+}$MDSCs and tolerogenic macrophages [196].

In addition, an earlier study comparing dysplastic lesions and cancers from patients with and without IBD showed that although IBD-associated dysplasia and cancer was associated with increased $\mathrm{CD} 8^{+} \mathrm{T}$ cell infiltration, these $\mathrm{CD} 8^{+} \mathrm{T}$ cells showed less expression of granzyme B and were thus less efficient in killing tumor cells [161] (Table 1). Furthermore, Yu et al. demonstrated that intratumoral $\mathrm{CD}^{+} \mathrm{T}$ cells in CAC mice display increased expression of the inhibitory markers PD-1 and CTLA-4, which may also indicate the presence of exhausted T cells [159]. This suppressive T-cell phenotype may contribute to tumor development, as effector cytokine production (IL-2, IFN- $\gamma$ ) is progressively lost in exhausted T cells [197], dampening effective immune responses against neoplastic cells. Similarly, upregulation of PD-1 expression in $\mathrm{T} \mathrm{CD} 8^{+}$intraepithelial lymphocytes in mice subjected to AOM/DSS was identified [160] (Table 1), which was likely induced by repetitive cycles of inflammation. In humans, it was shown that patients with UC-associated dysplasia and cancer had increased expression of the PD-1 ligand PD-L1 on CD8 ${ }^{+} \mathrm{T}$ cells, as compared to sporadic CRC. PD-L1 overexpression correlated to chronic inflammation-induced DNA damage, and PD-L1 upregulation was mediated by inflammation-induced upregulation of IRF-1 [198] (Table 1). Whether this exhaustion phenotype on T cells also leads to decreased effector functions of $\mathrm{T}$ cells, and thus interferes with their immunosurveillance function, needs further investigation.

Lastly, Tregs have an important immunomodulatory role in limiting excessive inflammatory immune responses. They counteract the inflammatory response, but in the setting of cancer, expansion of the Treg pool may shape an immunosuppressive niche in which tumors can progress (Figure 2). In the context of IBD-associated cancer, studies in the $\mathrm{AOM} / \mathrm{DSS}$ mouse model have shown that ablation of $\mathrm{CD} 4^{+} \mathrm{Foxp}^{+}$Treg cells suppressed tumor growth, which was associated with increased numbers of $\mathrm{CD} 8^{+} \mathrm{IFN}-\gamma^{+}$Granzyme B-producing effector T cells [162,163] (Table 1). This demonstrates how immunosuppressive Tregs may be involved in the pathophysiology of IBD-associated cancer. Apart from immunosuppressive Tregs, IL $17^{+} \mathrm{Foxp}^{+} \mathrm{CD} 4^{+} \mathrm{T}$ cells, which can be induced by TGF- $\beta$, and IL-2 were identified as a functional proinflammatory Treg subpopulation present in the mucosal tissues of patients with active UC and in patients with UC-associated cancer, but not in non-inflammatory cancers, indicating that this subset of Tregs may also play a role in CAC pathogenesis [199].

Another interesting Treg subset in the setting of intestinal inflammation-induced cancer is the Foxp3 $3^{+} \mathrm{ROR} \gamma \mathrm{t}^{+} \mathrm{T}$ cell. ROR $\gamma \mathrm{t}$ is a transcription factor other than Foxp3 which plays a role in Treg and Th17 differentiation. Studies have shown that ROR $\gamma \mathrm{t}^{+}$Treg cells promote inflammation and tumorigenesis by production of IL-17 [200], and they are observed in IBD and IBD-associated dysplastic lesions [201,202]. The tumor-promoting 
role of these cells has been demonstrated by Treg-specific deletion of ROR $\gamma \mathrm{t}$ in CAC mice, which resulted in decreased tumor incidence and decreased expression of ki67 and STAT3 in dysplastic lesions [202]. These data highlight the potential role for this Treg subset in IBD-associated tumorigenesis.

In summary, T cells exert a crucial function in killing neoplastic cells, but chronic inflammation as observed in IBD may induce an immunosuppressive environment with T-cell exhaustion and excessive Treg cell recruitment, which prevents adequate immunosurveillance and promotes evolution from non-dysplastic mucosa to dysplasia and/or carcinoma. In addition, pro-inflammatory Treg subpopulations such as IL-17-producing Tregs and Foxp $3^{+} \mathrm{ROR} \mathrm{t}^{+}$Tregs may contribute to cancer development in IBD. It will be interesting to unravel the role of these $\mathrm{T}$ cell subsets in IBD-associated dysplasia and cancer in humans.

\subsubsection{Innate Lymphoid Cells}

Innate lymphoid cells (ILCs) are a relatively recently discovered group of innate immune cells with diverse and important functions. They are generally classified in three types, with type 1 ILCs including NK cells. A large body of evidence demonstrates their role in IBD pathophysiology [203]. In line with this, patients with Crohn's disease have increased numbers of NK cells in the small intestinal epithelial compartment [204] and colonic lamina propria [205].

Apart from their role in inflammation, NK cells have important anti-tumorigenic functions and play a pivotal role in clearing cancer cells [206,207]. In IBD-associated cancer, it has been proposed that NK cells participate in anti-tumor immunity through IL-15 stimulation produced by CD11 $\mathrm{c}^{+}$DCs [208]. Specifically, AOM/DSS-treated mice that deleted IL-15 showed reduced survival and higher tumor incidence. Conversely, reconstitution of IL-15 expression selectively in CD11c ${ }^{+}$DCs restored NK cells and CD8 ${ }^{+}$ T-cell compartments, with a subsequent reduction in tumor burden.

In the setting of chronic inflammation, NK cell immunosurveillance capacity may be compromised. In a recent study that addressed metabolic and functional profile of blood circulating NK cells in IBD patients, it was demonstrated that these NK cells produce proinflammatory cytokines such as IL-17A and TNF- $\alpha$ ex vivo, but they show limited killing capacity and defective mitochondrial activity [164] (Table 1). It could be hypothesized that such defects in NK cell killing capacity as observed in IBD patients might contribute to decreased immunosurveillance.

Additionally, type 3 ILCs (ILC3s), the innate counterparts of Th17 cells from the adaptive immune system, may be involved in IBD-associated cancer formation. ILC3s secrete cytokines including IL-23, IL-17 and IL-22, all of which have pro-tumorigenic effects [209-211]. Accumulation of IL-17 ${ }^{+}$IL-22 ${ }^{+}$ILC3s was identified in the colonic mucosa from CAC mice. The authors demonstrated the contribution of these cells to tumorigenesis in the context of UC, since its depletion blocks the development of invasive cancer lesions from dysplastic precursors. Further mechanistic analyses showed that IL-22 produced by colonic ILC3s in CAC mice acts on IECs to induce STAT3 phosphorylation [212]. Given the already known pro-cancer effect of STAT3 immune signaling [213], this study demonstrates an active role of ILCs in dampening anti-tumoral immune responses.

Thus, even though some ILCs, such as NK cells, are vital for mounting adequate anti-tumor immune responses, other ILCs including ILC3s may have a pro-tumorigenic effects via secretion of pro-inflammatory cytokines.

\section{Conclusions}

Long-standing chronic inflammation as observed in the intestinal mucosa of IBD patients increases the risk of CRC. The genetic and molecular changes in IECs of IBD-associated cancers are well characterized, and the role of immune cell-derived pro-inflammatory mediators has been studied extensively, mostly using mouse models. 
Less studied potential mechanisms of CAC are the anti-inflammatory/immunosuppressive pathways that emerge during long lasting inflammation, which may create a niche for tumors to grow. It is already well-known that cancers can promote an immunosuppressive microenvironment favoring its own growth and progression. In recent years, this phenomenon has gained more attention, mainly due to the noticeable anti-tumor effects of immune checkpoint inhibitors, which revert to this immunosuppressive state and activate the immune system. Here, we provide an overview of different immune cells that are recruited into the inflamed mucosa of IBD patients and describe how these immune cells impact cancer development, either by anti- or pro-tumorigenic effects. For example, increased expression of T-cell inhibitory receptors such as PD-1 and CTLA-4 have been observed in intratumoral $\mathrm{CD} 4^{+}$and $\mathrm{CD} 8^{+} \mathrm{T}$ cells lesions in mouse models for inflammation-driven colorectal cancer, indicating that $\mathrm{T}$-cell suppression may be involved in the etiology of IBD-associated cancer. Although there are only limited data in humans, the chronic inflammation-induced immunosuppressive environment may thus be another mechanism driving colitis-associated cancer, not only by induction of dysfunctional, exhausted T cells, but also by the recruitment of Tregs, MDSCs and other suppressor cells into the inflamed intestinal mucosa.

It is important to understand the immunosuppressive mechanisms that evolve during chronic inflammation and may be involved in cancer development by allowing cancers to evade anti-tumor immune responses. This is especially the case for patients at high risk for developing IBD-associated dysplasia and cancer, such as patients with IBD and PSC. Additionally, better understanding of the mechanisms involved may dictate the choice of immunosuppressive drugs used in these patients.

Author Contributions: Writing—original draft preparation, S.F.; writing—review and editing, S.F., D.A.L., G.R.D. and J.G.; visualization, S.F. and D.A.L.; supervision, J.G.; funding acquisition, G.R.D. and J.G. All authors have read and agreed to the published version of the manuscript.

Funding: This research was funded by the Dutch Research Council (NWO) number 09150161810115 to J.G. This project has received funding from the European Union's Horizon 2020 research and innovation programme under the Marie Skłodowska-Curie grant agreement No 847551.

Institutional Review Board Statement: Not applicable.

Informed Consent Statement: Not applicable.

Data Availability Statement: Not applicable.

Conflicts of Interest: The authors declare no conflict of interest. The funders had no role in the design of the study; in the collection, analyses, or interpretation of data; in the writing of the manuscript, or in the decision to publish the results.

$\begin{array}{ll}\text { Abbreviations } \\ \text { 5-ASA } & \text { 5-Aminosalicylic acid } \\ \text { AOM } & \text { azoxymethane } \\ \text { APC } & \text { antigen presenting cell } \\ \text { CAC } & \text { colitis-associated cancer } \\ \text { CCL } & \text { C-C motif ligand } \\ \text { CCR } & \text { C-C chemokine receptor } \\ \text { CD } & \text { crohn's disease } \\ \text { CRC } & \text { colorectal cancer } \\ \text { CTLA-4 } & \text { cytotoxic T-lymphocyte-associated protein } \\ \text { CXCL } & \text { C-X-C motif ligand } \\ \text { CXCR } & \text { C-X-C chemokine receptor } \\ \text { DC } & \text { dendritic cell } \\ \text { DSS } & \text { dextran sodium sulphate } \\ \text { HGD } & \text { high-grade dysplasia } \\ \text { IBD } & \text { inflammatory bowel disease } \\ \text { IECs } & \text { intestinal epithelial cells }\end{array}$




\begin{tabular}{|c|c|}
\hline IFN- $\gamma$ & interferon-gamma \\
\hline IL & interleukin \\
\hline ILC & innate lymphoid cell \\
\hline ILC3 & type 3 innate lymphoid cell \\
\hline iNOS & inducible nitric oxide synthase \\
\hline LGD & low-grade dysplasia \\
\hline MDSC & myeloid-derived suppressor cell \\
\hline NK & natural killer \\
\hline PD-1 & programmed cell death protein 1 \\
\hline $\mathrm{pDC}$ & plasmacytoid dendritic cell \\
\hline PD-L1 & programmed death ligand 1 \\
\hline PSC & primary sclerosing cholangitis \\
\hline TGF- $\beta$ & transforming growth factor beta \\
\hline TNF- $\alpha$ & tumor necrosis factor alpha \\
\hline Th & helper T cell \\
\hline Treg & regulatory $\mathrm{T}$ cell \\
\hline $\mathrm{UC}$ & ulcerative colitis \\
\hline
\end{tabular}

\section{References}

1. Romano, M.; De Francesco, F.; Zarantonello, L.; Ruffolo, C.; Ferraro, G.A.; Zanus, G.; Giordano, A.; Bassi, N.; Cillo, U. From Inflammation to Cancer in Inflammatory Bowel Disease: Molecular Perspectives. Anticancer Res. 2016, 36, $1447-1460$.

2. Saraggi, D.; Fassan, M.; Mescoli, C.; Scarpa, M.; Valeri, N.; Michielan, A.; D’Incá, R.; Rugge, M. The molecular landscape of colitis-associated carcinogenesis. Dig. Liver Dis. 2017, 49, 326-330. [CrossRef]

3. Okayasu, I. Development of ulcerative colitis and its associated colorectal neoplasia as a model of the organ-specific chronic inflammation-carcinoma sequence. Pathol. Int. 2012, 62, 368-380. [CrossRef]

4. Lakatos, P.L.; Lakatos, L. Risk for colorectal cancer in ulcerative colitis: Changes, causes and management strategies. World J. Gastroenterol. 2008, 14, 3937-3947. [CrossRef]

5. Fantini, M.C.; Guadagni, I. From inflammation to colitis-associated colorectal cancer in inflammatory bowel disease: Pathogenesis and impact of current therapies. Dig. Liver Dis. 2021, 53, 558-565. [CrossRef]

6. $\quad$ Lennerz, J.K.; Van Der Sloot, K.W.J.; Le, L.P.; Batten, J.M.; Han, J.Y.; Fan, K.C.; Siegel, C.A.; Srivastava, A.; Park, Y.; Chen, J.-H.; et al. Colorectal cancer in Crohn's colitis is comparable to sporadic colorectal cancer. Int. J. Colorectal. Dis. 2016, 31, 973-982. [CrossRef]

7. Olén, O.; Erichsen, R.; Sachs, M.C.; Pedersen, L.; Halfvarson, J.; Askling, J.; Ekbom, A.; Sørensen, H.T.; Ludvigsson, J.F. Colorectal cancer in ulcerative colitis: A Scandinavian population-based cohort study. Lancet 2020, 395, 123-131. [CrossRef]

8. De Campos Silva, E.F.; Baima, J.P.; de Barros, J.R.; Tanni, S.E.; Schreck, T.; Saad-Hossne, R.; Sassaki, L.Y. Risk factors for ulcerative colitis-associated colorectal cancer: A retrospective cohort study. Medicine 2020, 99, e21686. [CrossRef] [PubMed]

9. Rogler, G. Chronic ulcerative colitis and colorectal cancer. Cancer Lett. 2014, 345, 235-241. [CrossRef] [PubMed]

10. Yvellez, O.V.; Rai, V.; Sossenheimer, P.H.; Hart, J.; Turner, J.R.; Weber, C.; El Jurdi, K.; Rubin, D.T. Cumulative Histologic Inflammation Predicts Colorectal Neoplasia in Ulcerative Colitis: A Validation Study. Inflamm. Bowel Dis. 2021, 27, 203-206. [CrossRef] [PubMed]

11. Porter, R.J.; Arends, M.J.; Churchhouse, A.M.D.; Din, S. Inflammatory bowel disease-associated colorectal cancer: Translational risks from mechanisms to medicines. J. Crohns Colitis 2021. Online ahead of print. [CrossRef]

12. Low, D.; Mino-Kenudson, M.; Mizoguchi, E. Recent advancement in understanding colitis-associated tumorigenesis. Inflamm. Bowel Dis. 2014, 20, 2115-2123. [CrossRef] [PubMed]

13. Beaugerie, L.; Itzkowitz, S.H. Cancers complicating inflammatory bowel disease. N. Engl. J. Med. 2015, 372, 1441-1452. [CrossRef] [PubMed]

14. Dulai, P.S.; Sandborn, W.J.; Gupta, S. Colorectal Cancer and Dysplasia in Inflammatory Bowel Disease: A Review of Disease Epidemiology, Pathophysiology, and Management. Cancer Prev. Res. 2016, 9, 887-894. [CrossRef]

15. Du, L.; Kim, J.J.; Shen, J.; Chen, B.; Dai, N. KRAS and TP53 mutations in inflammatory bowel disease-associated colorectal cancer: A meta-analysis. Oncotarget 2017, 8, 22175-22186. [CrossRef] [PubMed]

16. Popivanova, B.K.; Kitamura, K.; Wu, Y.; Kondo, T.; Kagaya, T.; Kaneko, S.; Oshima, M.; Fujii, C.; Mukaida, N. Blocking TNF-alpha in mice reduces colorectal carcinogenesis associated with chronic colitis. J. Clin. Investig. 2008, 118, 560-570.

17. Osawa, E.; Nakajima, A.; Fujisawa, T.; Kawamura, Y.I.; Toyama-Sorimachi, N.; Nakagama, H.; Dohi, T. Predominant T helper type 2-inflammatory responses promote murine colon cancers. Int. J. Cancer 2006, 118, 2232-2236. [CrossRef]

18. Jauch, D.; Martin, M.; Schiechl, G.; Kesselring, R.; Schlitt, H.J.; Geissler, E.K.; Fichtner-Feigl, S. Interleukin 21 controls tumour growth and tumour immunosurveillance in colitis-associated tumorigenesis in mice. Gut 2011, 60, 1678-1686. [CrossRef]

19. Punkenburg, E.; Vogler, T.; Büttner, M.; Amann, K.; Waldner, M.; Atreya, R.; Abendroth, B.; Mudter, J.; Merkel, S.; Gallmeier, E.; et al. Batf-dependent Th17 cells critically regulate IL-23 driven colitis-associated colon cancer. Gut 2016, 65, 1139-1150. [CrossRef] 
20. Matsumoto, S.; Hara, T.; Mitsuyama, K.; Yamamoto, M.; Tsuruta, O.; Sata, M.; Scheller, J.; Rose-John, S.; Kado, S.I.; Takada, T. Essential roles of IL-6 trans-signaling in colonic epithelial cells, induced by the IL-6/soluble-IL-6 receptor derived from lamina propria macrophages, on the development of colitis-associated premalignant cancer in a murine model. J. Immunol. 2010, 184, 1543-1551. [CrossRef]

21. Karvellas, C.J.; Fedorak, R.N.; Hanson, J.; Wong, C.K. Increased risk of colorectal cancer in ulcerative colitis patients diagnosed after 40 years of age. Can. J. Gastroenterol. 2007, 21, 443-446. [CrossRef]

22. Munkholm, P. Review article: The incidence and prevalence of colorectal cancer in inflammatory bowel disease. Aliment. Pharmacol. Ther. 2003, 18, 1-5. [CrossRef]

23. Selinger, C.P.; Andrews, J.M.; Titman, A.; Norton, I.; Jones, D.B.; McDonald, C.; Barr, G.; Selby, W.; Leong, R. Sydney IBD Cohort Study Group. Long-term follow-up reveals low incidence of colorectal cancer, but frequent need for resection, among Australian patients with inflammatory bowel disease. Clin. Gastroenterol. Hepatol. 2014, 12, 644-650. [CrossRef]

24. Gatenby, G.; Glyn, T.; Pearson, J.; Gearry, R.; Eglinton, T. The long-term incidence of dysplasia and colorectal cancer in a Crohn's colitis population-based cohort. Colorectal. Dis. 2021, 23, 2399-2406. [CrossRef] [PubMed]

25. Gajendran, M.; Loganathan, P.; Jimenez, G.; Catinella, A.P.; Ng, N.; Umapathy, C.; Ziade, N.; Hashash, J.G. A comprehensive review and update on ulcerative colitis. Dis. Mon. 2019, 65, 100851. [CrossRef] [PubMed]

26. Matkowskyj, K.A.; Chen, Z.E.; Rao, M.S.; Yang, G.Y. Dysplastic lesions in inflammatory bowel disease: Molecular pathogenesis to morphology. Arch. Pathol. Lab. Med. 2013, 137, 338-350. [CrossRef]

27. Riddell, R.H.; Goldman, H.; Ransohoff, D.F.; Appelman, H.D.; Fenoglio, C.M.; Haggitt, R.C.; Hren, C.; Correa, P.; Hamilton, S.R.; Morson, B.C.; et al. Dysplasia in inflammatory bowel disease: Standardized classification with provisional clinical applications. Hum. Pathol. 1983, 14, 931-968. [CrossRef]

28. Harpaz, N.; Ward, S.C.; Mescoli, C.; Itzkowitz, S.H.; Polydorides, A.D. Precancerous lesions in inflammatory bowel disease. Best Pract. Res. Clin. Gastroenterol. 2013, 27, 257-267. [CrossRef]

29. Gui, X.; Iacucci, M.; Ghosh, S.; Ferraz, J.G.P.; Lee, S. Revisiting the distinct histomorphologic features of inflammatory bowel disease-associated neoplastic precursor lesions in the SCENIC and post-DALM Era. Hum. Pathol. 2020, 100, 24-37. [CrossRef]

30. Chiu, K.; Riddell, R.H.; Schaeffer, D.F. DALM, rest in peace: A pathologist's perspective on dysplasia in inflammatory bowel disease in the post-DALM era. Mod. Pathol. 2018, 31, 1180-1190. [CrossRef] [PubMed]

31. Hagland, H.R.; Berg, M.; Jolma, I.W.; Carlsen, A.; Søreide, K. Molecular pathways and cellular metabolism in colorectal cancer. Dig. Surg. 2013, 30, 12-25. [CrossRef] [PubMed]

32. Xie, J.; Itzkowitz, S.H. Cancer in inflammatory bowel disease. World J. Gastroenterol. 2008, 14, 378-389. [CrossRef]

33. Wijnands, A.M.; de Jong, M.E.; Lutgens, M.; Hoentjen, F.; Elias, S.G.; Oldenburg, B.; Dutch Initiative on Crohn and Colitis (ICC). Prognostic Factors for Advanced Colorectal Neoplasia in Inflammatory Bowel Disease: Systematic Review and Meta-analysis. Gastroenterology 2021, 160, 1584-1598. [CrossRef]

34. Löwenberg, M.; Van Der Vlugt, M. Risk of Progression of Low-Grade Dysplasia to Advanced Neoplasia in Inflammatory Bowel Disease. J. Crohns Colitis 2019, 13, 1483-1484. [CrossRef] [PubMed]

35. Bezzio, C.; Festa, S.; Saibeni, S.; Papi, C. Chemoprevention of colorectal cancer in ulcerative colitis: Digging deep in current evidence. Expert Rev. Gastroenterol. Hepatol. 2017, 11, 339-347. [CrossRef]

36. Lopez, A.; Pouillon, L.; Beaugerie, L.; Danese, S.; Peyrin-Biroulet, L. Colorectal cancer prevention in patients with ulcerative colitis. Best Pract. Res. Clin. Gastroenterol. 2018, 32-33, 103-109. [CrossRef] [PubMed]

37. Lamb, C.A.; Kennedy, N.A.; Raine, T.; Hendy, P.A.; Smith, P.J.; Limdi, J.K.; Hayee, B.H.; Lomer, M.C.; Parkes, G.C.; Selinger, C.; et al. British Society of Gastroenterology consensus guidelines on the management of inflammatory bowel disease in adults. Gut 2019, 68 (Suppl. 3), s1-s106. [CrossRef]

38. Nagahori, M.; Kochi, S.; Hanai, H.; Yamamoto, T.; Nakamura, S.; Omuro, S.; Watanabe, M.; Hibi, T. Real life results in using 5-ASA for maintaining mild to moderate UC patients in Japan, a multi-center study, OPTIMUM Study. BMC Gastroenterol. 2017, 17, 47. [CrossRef]

39. Van de Meeberg, M.M.; Schultheiss, J.P.D.; Oldenburg, B.; Fidder, H.H.; Huitema, A.D.R. Does the 5-Aminosalicylate Concentration Correlate with the Efficacy of Oral 5-Aminosalicylate and Predict Response in Patients with Inflammatory Bowel Disease? A Systematic Review. Digestion 2020, 101, 245-261. [CrossRef]

40. Koelink, P.J.; Robanus-Maandag, E.C.; Devilee, P.; Hommes, D.W.; Lamers, C.B.; Verspaget, H.W. 5-Aminosalicylic acid inhibits colitis-associated but not sporadic colorectal neoplasia in a novel conditional Apc mouse model. Carcinogenesis 2009, 30, 1217-1224. [CrossRef]

41. Bos, C.L.; Diks, S.H.; Hardwick, J.C.; Walburg, K.V.; Peppelenbosch, M.P.; Richel, D.J. Protein phosphatase 2A is required for mesalazine-dependent inhibition of Wnt/beta-catenin pathway activity. Carcinogenesis 2006, 27, 2371-2382. [CrossRef]

42. Campregher, C.; Honeder, C.; Chung, H.; Carethers, J.M.; Gasche, C. Mesalazine reduces mutations in transforming growth factor beta receptor II and activin type II receptor by improvement of replication fidelity in mononucleotide repeats. Clin. Cancer Res. 2010, 16, 1950-1956. [CrossRef] [PubMed]

43. Nguyen, G.C.; Gulamhusein, A.; Bernstein, C.N. 5-aminosalicylic acid is not protective against colorectal cancer in inflammatory bowel disease: A meta-analysis of non-referral populations. Am. J. Gastroenterol. 2012, 107, 1298-1304. [CrossRef] [PubMed]

44. Zhao, L.N.; Li, J.Y.; Yu, T.; Chen, G.C.; Yuan, Y.H.; Chen, Q.K. 5-Aminosalicylates reduce the risk of colorectal neoplasia in patients with ulcerative colitis: An updated meta-analysis. PLoS ONE 2014, 9, e94208. [CrossRef] [PubMed] 
45. Axelrad, J.E.; Roy, A.; Lawlor, G.; Korelitz, B.; Lichtiger, S. Thiopurines and inflammatory bowel disease: Current evidence and a historical perspective. World J. Gastroenterol. 2016, 22, 10103-10117. [CrossRef]

46. Zhu, Z.; Mei, Z.; Guo, Y.; Wang, G.; Wu, T.; Cui, X.; Huang, Z.; Zhu, Y.; Wen, D.; Song, J.; et al. Reduced Risk of Inflammatory Bowel Disease-associated Colorectal Neoplasia with Use of Thiopurines: A Systematic Review and Meta-analysis. J. Crohns Colitis 2018, 12, 546-558. [CrossRef]

47. Carrat, F.; Seksik, P.; Colombel, J.F.; Peyrin-Biroulet, L.; Beaugerie, L. The effects of aminosalicylates or thiopurines on the risk of colorectal cancer in inflammatory bowel disease. Aliment. Pharmacol. Ther. 2017, 45, 533-541. [CrossRef]

48. Lu, M.J.; Qiu, X.Y.; Mao, X.Q.; Li, X.T.; Zhang, H.H.H.J. Systematic review with meta-analysis: Thiopurines decrease the risk of colorectal neoplasia in patients with inflammatory bowel disease. Aliment. Pharmacol. Ther. 2018, 47, 318-331. [CrossRef]

49. Fleit, H.B. Chronic Inflammation. In Pathobiology of Human Disease; McManus, L.M., Mitchell, R.N., Eds.; Academic Press: San Diego, CA, USA, 2014; pp. 300-314.

50. Gonzalez, H.; Hagerling, C.; Werb, Z. Roles of the immune system in cancer: From tumor initiation to metastatic progression. Genes Dev. 2018, 32, 1267-1284. [CrossRef]

51. Korniluk, A.; Koper, O.; Kemona, H.; Dymicka-Piekarska, V. From inflammation to cancer. Irish J. Med. Sci. 2017, 186, 57-62. [CrossRef]

52. Singh, N.; Baby, D.; Rajguru, J.P.; Patil, P.B.; Thakkannavar, S.S.; Pujari, V.B. Inflammation and cancer. Ann. Afr. Med. 2019, 18, 121-126. [CrossRef]

53. Ohata, H.; Kitauchi, S.; Yoshimura, N.; Mugitani, K.; Iwane, M.; Nakamura, H.; Yoshikawa, A.; Yanaoka, K.; Arii, K.; Tamai, $\mathrm{H}$; et al. Progression of chronic atrophic gastritis associated with Helicobacter pylori infection increases risk of gastric cancer. Int. J. Cancer 2004, 109, 138-143. [CrossRef]

54. Wroblewski, L.E.; Peek, R.M., Jr.; Wilson, K.T. Helicobacter pylori and gastric cancer: Factors that modulate disease risk. Clin. Microbiol. Rev. 2010, 23, 713-739. [CrossRef]

55. Zhang, X.Y.; Zhang, P.Y.; Aboul-Soud, M.A.M. From inflammation to gastric cancer: Role of Helicobacter pylori. Oncol. Lett. 2017, 13, 543-548. [CrossRef]

56. Nair, S.; Pillai, M.R. Human papillomavirus and disease mechanisms: Relevance to oral and cervical cancers. Oral Dis. 2005, 11, 350-359. [CrossRef] [PubMed]

57. Centers for Disease Control and Prevention. Human papillomavirus-associated cancers-United States, 2004-2008. MMWR Morb. Mortal. Wkly. Rep. 2012, 61, 258-261.

58. El-Serag, H.B. Epidemiology of viral hepatitis and hepatocellular carcinoma. Gastroenterology 2012, 142, 1264-1273. [CrossRef]

59. Teng, W.; Liu, Y.C.; Jeng, W.J.; Su, C.W. Tertiary Prevention of HCC in Chronic Hepatitis B or C Infected Patients. Cancers 2021, 13, 1729. [CrossRef]

60. Palmela, C.; Peerani, F.; Castaneda, D.; Torres, J.; Itzkowitz, S.H. Inflammatory Bowel Disease and Primary Sclerosing Cholangitis: A Review of the Phenotype and Associated Specific Features. Gut Liver 2018, 12, 17-29. [CrossRef] [PubMed]

61. Axelrad, J.E.; Lichtiger, S.; Yajnik, V. Inflammatory bowel disease and cancer: The role of inflammation, immunosuppression, and cancer treatment. World J. Gastroenterol. 2016, 22, 4794-4801. [CrossRef] [PubMed]

62. Munn, L.L. Cancer and inflammation. Wiley Interdiscip. Rev. Syst. Biol. Med. 2017, 9, e1370. [CrossRef]

63. Kay, J.; Thadhani, E.; Samson, L.; Engelward, B. Inflammation-induced DNA damage, mutations and cancer. DNA Repair 2019, 83, 102673. [CrossRef]

64. Zhao, H.; Wu, L.; Yan, G.; Chen, Y.; Zhou, M.; Wu, Y.; Li, Y. Inflammation and tumor progression: Signaling pathways and targeted intervention. Signal. Transduct. Target. Ther. 2021, 6, 263. [CrossRef]

65. Korneev, K.V.; Atretkhany, K.N.; Drutskaya, M.S.; Grivennikov, S.I.; Kuprash, D.V.; Nedospasov, S.A. TLR-signaling and proinflammatory cytokines as drivers of tumorigenesis. Cytokine 2017, 89, 127-135. [CrossRef]

66. Greten, F.R.; Grivennikov, S.I. Inflammation and Cancer: Triggers, Mechanisms, and Consequences. Immunity 2019, 51, $27-41$. [CrossRef]

67. Grivennikov, S.I.; Karin, M. Inflammatory cytokines in cancer: Tumour necrosis factor and interleukin 6 take the stage. Ann. Rheum Dis. 2011, 70 (Suppl. 1), i104-i108. [CrossRef]

68. Li, R.; Wen, A.; Lin, J. Pro-Inflammatory Cytokines in the Formation of the Pre-Metastatic Niche. Cancers 2020, 12, 3752. [CrossRef] [PubMed]

69. Wang, S.; Song, R.; Wang, Z.; Jing, Z.; Wang, S.; Ma, J.S. S100A8/A9 in Inflammation. Front. Immunol. 2018, 9, 1298. [CrossRef]

70. Németh, J.; Stein, I.; Haag, D.; Riehl, A.; Longerich, T.; Horwitz, E.; Breuhahn, K.; Gebhardt, C.; Schirmacher, P.; Hahn, M.; et al. S100A8 and S100A9 are novel nuclear factor kappa B target genes during malignant progression of murine and human liver carcinogenesis. Hepatology 2009, 50, 1251-1262. [CrossRef] [PubMed]

71. Shabani, F.; Farasat, A.; Mahdavi, M.; Gheibi, N. Calprotectin (S100A8/S100A9): A key protein between inflammation and cancer. Inflamm. Res. 2018, 67, 801-812. [CrossRef] [PubMed]

72. Montrose, D.C.; Nakanishi, M.; Murphy, R.C.; Zarini, S.; McAleer, J.P.; Vella, A.T.; Rosenberg, D.W. The role of PGE2 in intestinal inflammation and tumorigenesis. Prostaglandins Other Lipid Mediat. 2015, 116-117, 26-36. [CrossRef]

73. Hirano, T.; Hirayama, D.; Wagatsuma, K.; Yamakawa, T.; Yokoyama, Y.; Nakase, H. Immunological Mechanisms in InflammationAssociated Colon Carcinogenesis. Int. J. Mol. Sci. 2020, 21, 3062. [CrossRef] 
74. Finetti, F.; Travelli, C.; Ercoli, J.; Colombo, G.; Buoso, E.; Trabalzini, L. Prostaglandin E2 and Cancer: Insight into Tumor Progression and Immunity. Biology 2020, 9, 434. [CrossRef] [PubMed]

75. Aoki, T.; Narumiya, S. Prostaglandin E(2)-EP2 signaling as a node of chronic inflammation in the colon tumor microenvironment. Inflamm. Regen. 2017, 37, 4. [CrossRef] [PubMed]

76. Fan, Y.; Mao, R.; Yang, J. NF-kB and STAT3 signaling pathways collaboratively link inflammation to cancer. Protein Cell. 2013, 4 176-185. [CrossRef]

77. Bollrath, J.; Phesse, T.J.; von Burstin, V.A.; Putoczki, T.; Bennecke, M.; Bateman, T.; Nebelsiek, T.; Lundgren-May, T.; Canli, Ö.; Schwitalla, S.; et al. gp130-Mediated Stat3 Activation in Enterocytes Regulates Cell Survival and Cell-Cycle Progression during Colitis-Associated Tumorigenesis. Cancer Cell 2009, 15, 91-102. [CrossRef] [PubMed]

78. Raman, D.; Baugher, P.J.; Thu, Y.M.; Richmond, A. Role of chemokines in tumor growth. Cancer Lett. 2007, 256, 137-165. [CrossRef]

79. Mollica Poeta, V.; Massara, M.; Capucetti, A.; Bonecchi, R. Chemokines and Chemokine Receptors: New Targets for Cancer Immunotherapy. Front. Immunol. 2019, 10, 379. [CrossRef]

80. Rani, A.; Dasgupta, P.; Murphy, J.J. Prostate Cancer: The Role of Inflammation and Chemokines. Am. J. Pathol. 2019, 189, 2119-2137. [CrossRef]

81. Burns, J.M.; Summers, B.C.; Wang, Y.; Melikian, A.; Berahovich, R.; Miao, Z.; Penfold, M.E.T.; Sunshine, M.J.; Littman, D.R.; Kuo, C.J.; et al. A novel chemokine receptor for SDF-1 and I-TAC involved in cell survival, cell adhesion, and tumor development. J. Exp. Med. 2006, 203, 2201-2213. [CrossRef]

82. Salcedo, R.; Ponce, M.L.; Young, H.A.; Wasserman, K.; Ward, J.M.; Kleinman, H.K.; Oppenheim, J.J.; Murphy, W.J. Human endothelial cells express CCR2 and respond to MCP-1: Direct role of MCP-1 in angiogenesis and tumor progression. Blood 2000, 96, 34-40. [CrossRef] [PubMed]

83. Lee, L.F.; Louie, M.C.; Desai, S.J.; Yang, J.; Chen, H.W.; Evans, C.P.; Kung, H.J. Interleukin-8 confers androgen-independent growth and migration of LNCaP: Differential effects of tyrosine kinases Src and FAK. Oncogene 2004, 23, 2197-2205. [CrossRef] [PubMed]

84. Ueha, S.; Shand, F.; Matsushima, K. Cellular and Molecular Mechanisms of Chronic Inflammation-Associated Organ Fibrosis. Front. Immunol. 2012, 3, 71. [CrossRef]

85. Braga, T.T.; Agudelo, J.S.H.; Camara, N.O.S. Macrophages During the Fibrotic Process: M2 as Friend and Foe. Front. Immunol. 2015, 6, 602. [CrossRef]

86. Hao, N.B.; Lü, M.H.; Fan, Y.H.; Cao, Y.L.; Zhang, Z.R.; Yang, S.M. Macrophages in Tumor Microenvironments and the Progression of Tumors. Clin. Dev. Immunol. 2012, 2012, 948098. [CrossRef]

87. Atri, C.; Guerfali, F.Z.; Laouini, D. Role of Human Macrophage Polarization in Inflammation during Infectious Diseases. Int. J. Mol. Sci. 2018, 19, 1801. [CrossRef]

88. Italiani, P.; Boraschi, D. From Monocytes to M1/M2 Macrophages: Phenotypical vs. Functional Differentiation. Front. Immunol. 2014, 5, 514. [CrossRef] [PubMed]

89. Jetten, N.; Verbruggen, S.; Gijbels, M.J.; Post, M.J.; De Winther, M.P.; Donners, M.M. Anti-inflammatory M2, but not proinflammatory M1 macrophages promote angiogenesis in vivo. Angiogenesis 2014, 17, 109-118. [CrossRef]

90. Zhao, G.; Liu, L.; Peek, R.M.; Hao, X.; Polk, D.B.; Li, H.; Yan, F. Activation of Epidermal Growth Factor Receptor in Macrophages Mediates Feedback Inhibition of M2 Polarization and Gastrointestinal Tumor Cell Growth. J. Biol. Chem. 2016, 291 , 20462-20472. [CrossRef]

91. Haque, A.S.M.R.; Moriyama, M.; Kubota, K.; Ishiguro, N.; Sakamoto, M.; Chinju, A.; Mochizuki, K.; Sakamoto, T.; Kaneko, N.; Munemura, R.; et al. CD206+ tumor-associated macrophages promote proliferation and invasion in oral squamous cell carcinoma via EGF production. Sci. Rep. 2019, 9, 14611. [CrossRef]

92. Kanterman, J.; Sade-Feldman, M.; Baniyash, M. New insights into chronic inflammation-induced immunosuppression. Semin. Cancer Biol. 2012, 22, 307-318. [CrossRef]

93. Wang, D.; DuBois, R.N. Immunosuppression associated with chronic inflammation in the tumor microenvironment. Carcinogenesis 2015, 36, 1085-1093. [CrossRef]

94. Lorusso, G.; Rüegg, C. The tumor microenvironment and its contribution to tumor evolution toward metastasis. Histochem. Cell Biol. 2008, 130, 1091-1103. [CrossRef]

95. Rao, S.; Gharib, K.; Han, A. Chapter Five-Cancer Immunosurveillance by T Cells. In International Review of Cell and Molecular Biology; Galluzzi, L., Rudqvist, N.-P., Eds.; Academic Press: San Diego, CA, USA, 2019; pp. 149-173.

96. Belkaid, Y.; Oldenhove, G. Tuning microenvironments: Induction of regulatory T cells by dendritic cells. Immunity 2008, 29 , 362-371. [CrossRef]

97. Zhao, H.; Liao, X.; Kang, Y. Tregs: Where We Are and What Comes Next? Front. Immunol. 2017, 8, 1578. [CrossRef] [PubMed]

98. Kryczek, I.; Wei, S.; Zou, L.; Zhu, G.; Mottram, P.; Xu, H.; Chen, L.; Zou, W. Cutting edge: Induction of B7-H4 on APCs through IL-10: Novel suppressive mode for regulatory T cells. J. Immunol. 2006, 177, 40-44. [CrossRef] [PubMed]

99. Von Boehmer, H. Mechanisms of suppression by suppressor T cells. Nat. Immunol. 2005, 6, 338-344. [CrossRef]

100. Beswick, E.J.; Johnson, J.R.; Saada, J.I.; Humen, M.; House, J.; Dann, S.; Qiu, S.; Brasier, A.R.; Powell, D.W.; Reyes, V.E.; et al. TLR4 activation enhances the PD-L1-mediated tolerogenic capacity of colonic CD90+ stromal cells. J. Immunol. 2014, 193, 2218-2229. [CrossRef] [PubMed] 
101. Zhang, X.; Zeng, Y.; Qu, Q.; Zhu, J.; Liu, Z.; Ning, W.; Zeng, H.; Zhang, N.; Du, W.; Chen, C.; et al. PD-L1 induced by IFN- $\gamma$ from tumor-associated macrophages via the JAK/STAT3 and PI3K/AKT signaling pathways promoted progression of lung cancer. Int. J. Clin. Oncol. 2017, 22, 1026-1033. [CrossRef]

102. Barber, D.L.; Wherry, E.J.; Masopust, D.; Zhu, B.; Allison, J.; Sharpe, A.H.; Freeman, G.J.; Ahmed, R. Restoring function in exhausted CD8 T cells during chronic viral infection. Nature 2006, 439, 682-687. [CrossRef]

103. Petrelli, A.; Mijnheer, G.; van Konijnenburg, D.H.; Van Der Wal, M.M.; Giovannone, B.; Mocholi, E.; Vazirpanah, N.; Broen, J.C.; Hijnen, D.; Oldenburg, B.; et al. PD-1+CD8+ T cells are clonally expanding effectors in human chronic inflammation. J. Clin. Investig. 2018, 128, 4669-4681. [CrossRef]

104. Freeman, G.J.; Long, A.J.; Iwai, Y.; Bourque, K.; Chernova, T.; Nishimura, H.; Fitz, L.J.; Malenkovich, N.; Okazaki, T.; Byrne, M.C.; et al. Engagement of the PD-1 immunoinhibitory receptor by a novel B7 family member leads to negative regulation of lymphocyte activation. J. Exp. Med. 2000, 192, 1027-1034. [CrossRef]

105. Yu, H.; Lin, L.; Zhang, Z.; Zhang, H.; Hu, H. Targeting NF-кB pathway for the therapy of diseases: Mechanism and clinical study. Signal. Transduct. Target. Ther. 2020, 5, 209. [CrossRef]

106. Sun, S.C. The non-canonical NF-кB pathway in immunity and inflammation. Nat. Rev. Immunol. 2017, 17, 545-558. [CrossRef]

107. Atreya, I.; Atreya, R.; Neurath, M.F. NF-kappaB in inflammatory bowel disease. J. Intern. Med. 2008, 263, 591-596. [CrossRef]

108. Schottelius, A.J.; Baldwin, A.S., Jr. A role for transcription factor NF-kappa B in intestinal inflammation. Int. J. Colorectal. Dis. 1999, 14, 18-28. [CrossRef]

109. Viennois, E.; Chen, F.; Merlin, D. NF-кB pathway in colitis-associated cancers. Transl. Gastrointest. Cancer 2013, 2, $21-29$.

110. Greten, F.R.; Eckmann, L.; Greten, T.F.; Park, J.M.; Li, Z.W.; Egan, L.J.; Kagnoff, M.F.; Karin, M. IKKbeta links inflammation and tumorigenesis in a mouse model of colitis-associated cancer. Cell 2004, 118, 285-296. [CrossRef] [PubMed]

111. Allen, I.C.; Wilson, J.E.; Schneider, M.; Lich, J.D.; Roberts, R.A.; Arthur, J.C.; Woodford, R.M.T.; Davis, B.K.; Uronis, J.M.; Herfarth, H.H.; et al. NLRP12 suppresses colon inflammation and tumorigenesis through the negative regulation of noncanonical NF- $\mathrm{B}$ signaling. Immunity 2012, 36, 742-754. [CrossRef] [PubMed]

112. Kumar, A.; Chatterjee, I.; Gujral, T.; Alakkam, A.; Coffing, H.; Anbazhagan, A.N.; Borthakur, A.; Saksena, S.; Gill, R.K.; Alrefai, W.A.; et al. Activation of Nuclear Factor- $\mathrm{kB}$ by Tumor Necrosis Factor in Intestinal Epithelial Cells and Mouse Intestinal Epithelia Reduces Expression of the Chloride Transporter SLC26A3. Gastroenterology 2017, 153, 1338-1350. [CrossRef] [PubMed]

113. Wang, Z.; Wu, X.; Wang, C.L.; Wang, L.; Sun, C.; Zhang, D.B.; Liu, J.L.; Liang, Y.N.; Tang, D.X.; Tang, Z.S. Tryptanthrin Protects Mice against Dextran Sulfate Sodium-Induced Colitis through Inhibition of TNF- $\alpha /$ NF- $\mathrm{kB}$ and IL-6/STAT3 Pathways. Molecules 2018, 23, 1062. [CrossRef] [PubMed]

114. Grivennikov, S.I. Inflammation and colorectal cancer: Colitis-associated neoplasia. Semin. Immunopathol. 2013, 35, 229-244. [CrossRef] [PubMed]

115. Ba, H.; Jiang, R.; Zhang, M.; Yin, B.; Wang, J.; Li, Z.; Li, B.; Zhou, X. Suppression of Transmembrane Tumor Necrosis Factor Alpha Processing by a Specific Antibody Protects Against Colitis-Associated Cancer. Front. Immunol. 2021, 12, 687874. [CrossRef] [PubMed]

116. Zidi, I.; Mestiri, S.; Bartegi, A.; Amor, N.B. TNF-alpha and its inhibitors in cancer. Med. Oncol. 2010, 27, 185-198. [CrossRef]

117. Caspersen, S.; Elkjaer, M.; Riis, L.; Pedersen, N.; Mortensen, C.; Jess, T.; Sarto, P.; Hansen, T.S.; Wewer, V.; Bendtsen, F.; et al. Infliximab for inflammatory bowel disease in Denmark 1999-2005: Clinical outcome and follow-up evaluation of malignancy and mortality. Clin. Gastroenterol. Hepatol. 2008, 6, 1212-1217. [CrossRef]

118. Schnitzler, F.; Fidder, H.; Ferrante, M.; Noman, M.; Arijs, I.; Van Assche, G.; Hoffman, I.; Van Steen, K.; Vermeire, S.; Rutgeerts, P. Long-term outcome of treatment with infliximab in 614 patients with Crohn's disease: Results from a single-centre cohort. Gut 2009, 58, 492-500. [CrossRef]

119. Neurath, M.F. New targets for mucosal healing and therapy in inflammatory bowel diseases. Mucosal Immunol. 2014, 7, 6-19. [CrossRef]

120. Li, Y.; de Haar, C.; Chen, M.; Deuring, J.; Gerrits, M.M.; Smits, R.; Xia, B.; Kuipers, E.J.; van der Woude, C.J. Disease-related expression of the IL6/STAT3/SOCS3 signalling pathway in ulcerative colitis and ulcerative colitis-related carcinogenesis. Gut 2010, 59, 227-235. [CrossRef]

121. Grivennikov, S.; Karin, E.; Terzic, J.; Mucida, D.; Yu, G.-Y.; Vallabhapurapu, S.; Scheller, J.; Rose-John, S.; Cheroutre, H.; Eckmann, L.; et al. IL-6 and Stat3 are required for survival of intestinal epithelial cells and development of colitis-associated cancer. Cancer Cell 2009, 15, 103-113. [CrossRef]

122. Backert, I.; Koralov, S.; Wirtz, S.; Kitowski, V.; Billmeier, U.; Martini, E.; Hofmann, K.; Hildner, K.; Wittkopf, N.; Brecht, K.; et al. STAT3 activation in Th17 and Th22 cells controls IL-22-mediated epithelial host defense during infectious colitis. J. Immunol. 2014, 193, 3779-3791. [CrossRef]

123. Nguyen, P.M.; Putoczki, T.L.; Ernst, M. STAT3-Activating Cytokines: A Therapeutic Opportunity for Inflammatory Bowel Disease? J. Interferon Cytokine Res. 2015, 35, 340-350. [CrossRef]

124. Pickert, G.; Neufert, C.; Leppkes, M.; Zheng, Y.; Wittkopf, N.; Warntjen, M.; Lehr, H.-A.; Hirth, S.; Weigmann, B.; Wirtz, S.; et al. STAT3 links IL-22 signaling in intestinal epithelial cells to mucosal wound healing. J. Exp. Med. 2009, 206, 1465-1472. [CrossRef]

125. Yu, L.Z.; Wang, H.Y.; Yang, S.P.; Yuan, Z.P.; Xu, F.Y.; Sun, C.; Shi, R.H. Expression of interleukin-22/STAT3 signaling pathway in ulcerative colitis and related carcinogenesis. World J. Gastroenterol. 2013, 19, 2638-2649. [CrossRef] 
126. Jiang, R.; Wang, H.; Deng, L.; Hou, J.; Shi, R.; Yao, M.; Gao, Y.; Yao, A.; Wang, X.; Yu, L.; et al. IL-22 is related to development of human colon cancer by activation of STAT3. BMC Cancer 2013, 13, 59. [CrossRef]

127. Pan, M.G.; Xiong, Y.; Chen, F. NFAT gene family in inflammation and cancer. Curr. Mol. Med. 2013, 13, 543-554. [CrossRef] [PubMed]

128. Liu, Z.; Lee, J.; Krummey, S.; Lu, W.; Cai, H.; Lenardo, M.J. The kinase LRRK2 is a regulator of the transcription factor NFAT that modulates the severity of inflammatory bowel disease. Nat. Immunol. 2011, 12, 1063-1070. [CrossRef] [PubMed]

129. Weigmann, B.; Lehr, H.A.; Yancopoulos, G.; Valenzuela, D.; Murphy, A.; Stevens, S.; Schmidt, J.; Galle, P.R.; Rose-John, S.; Neurath, M.F. The transcription factor NFATc2 controls IL-6-dependent T cell activation in experimental colitis. J. Exp. Med. 2008, 205, 2099-2110. [CrossRef] [PubMed]

130. Gerlach, K.; Daniel, C.; Lehr, H.A.; Nikolaev, A.; Gerlach, T.; Atreya, R.; Rose-John, S.; Neurath, M.F.; Weigmann, B. Transcription factor NFATc2 controls the emergence of colon cancer associated with IL-6-dependent colitis. Cancer Res. 2012, 72, 4340-4350. [CrossRef]

131. Lin, Y.; Koumba, M.H.; Qu, S.; Wang, D.; Lin, L. Blocking NFATc3 ameliorates azoxymethane/dextran sulfate sodium induced colitis-associated colorectal cancer in mice via the inhibition of inflammatory responses and epithelial-mesenchymal transition. Cell. Signal. 2020, 74, 109707. [CrossRef]

132. Schmitt, H.; Neurath, M.F.; Atreya, R. Role of the IL23/IL17 Pathway in Crohn's Disease. Front. Immunol. 2021, $12,622934$. [CrossRef]

133. Bunte, K.; Beikler, T. Th17 Cells and the IL-23/IL-17 Axis in the Pathogenesis of Periodontitis and Immune-Mediated Inflammatory Diseases. Int. J. Mol. Sci. 2019, 20, 3394. [CrossRef]

134. Qi, H.; Yang, H.; Xu, G.; Ren, J.; Hua, W.; Shi, Y.; Torsvik, M.; Florholmen, J.; Cui, G. Therapeutic efficacy of IL-17A antibody injection in preventing the development of colitis associated carcinogenesis in mice. Immunobiology 2015, 220, 54-59. [CrossRef]

135. Eken, A.; Oukka, M. Interleukin 23 in IBD Pathogenesis. In New Insights into Inflammatory Bowel Disease; Samuel Huber, IntechOpen: London, UK, 2016; pp. 93-123.

136. Hyun, Y.S.; Han, D.S.; Lee, A.R.; Eun, C.S.; Youn, J.; Kim, H.Y. Role of IL-17A in the development of colitis-associated cancer. Carcinogenesis 2012, 33, 931-936. [CrossRef]

137. Fiorino, G.; Allocca, M.; Correale, C.; Roda, G.; Furfaro, F.; Loy, L.; Zilli, A.; Peyrin-Biroulet, L.; Danese, S. Positioning ustekinumab in moderate-to-severe ulcerative colitis: New kid on the block. Expert Opin. Biol. Ther. 2020, 20, 421-427. [CrossRef] [PubMed]

138. Argollo, M.C.; Allocca, M.; Furfaro, F.; Peyrin-Biroulet, L.; Danese, S. Interleukin-23 Blockers: Born to be First-line Biologic Agents in Inflammatory Bowel Disease? Curr. Pharm. Des. 2019, 25, 25-31. [CrossRef] [PubMed]

139. Smyth, M.J.; Taniguchi, M.; Street, S.E. The anti-tumor activity of IL-12: Mechanisms of innate immunity that are model and dose dependent. J. Immunol. 2000, 165, 2665-2670. [CrossRef]

140. Teng, M.W.; Vesely, M.D.; Duret, H.; McLaughlin, N.; Towne, J.E.; Schreiber, R.D.; Smyth, M.J. Opposing roles for IL-23 and IL-12 in maintaining occult cancer in an equilibrium state. Cancer Res. 2012, 72, 3987-3996. [CrossRef]

141. Sands, B.E.; Sandborn, W.J.; Panaccione, R.; O’Brien, C.D.; Zhang, H.; Johanns, J.; Adedokun, O.J.; Roblin, X.; Peyrin-Biroulet, L.; Van Assche, G.; et al. Ustekinumab as Induction and Maintenance Therapy for Ulcerative Colitis. N. Engl. J. Med. 2019, 381, 1201-1214. [CrossRef]

142. Bain, C.C.; Mowat, A.M. Macrophages in intestinal homeostasis and inflammation. Immunol. Rev. 2014, 260, 102-117. [CrossRef]

143. Mowat, A.M. To respond or not to respond-A personal perspective of intestinal tolerance. Nat. Rev. Immunol. 2018, 18, 405-415. [CrossRef] [PubMed]

144. Bain, C.C.; Scott, C.L.; Uronen-Hansson, H.; Gudjonsson, S.; Jansson, O.; Grip, O.; Guilliams, M.; Malissen, B.; Agace, W.W.; Mowat, A.M. Resident and pro-inflammatory macrophages in the colon represent alternative contex.xt-dependent fates of the same Ly6Chi monocyte precursors. Mucosal Immunol. 2013, 6, 498-510. [CrossRef]

145. Thiesen, S.; Janciauskiene, S.; Uronen-Hansson, H.; Agace, W.; Högerkorp, C.-M.; Spee, P.; Håkansson, K.; Grip, O. CD14(hi)HLADR(dim) macrophages, with a resemblance to classical blood monocytes, dominate inflamed mucosa in Crohn's disease. J. Leukoc. Biol. 2014, 95, 531-541. [CrossRef]

146. Bernardo, D.; Marin, A.C.; Fernández-Tomé, S.; Montalban-Arques, A.; Carrasco, A.; Tristán, E.; Ortega-Moreno, L.; MoraGutiérrez, I.; Díaz-Guerra, A.; Caminero-Fernández, R.; et al. Human intestinal pro-inflammatory CD11c(high)CCR2(+)CX3CR1(+) macrophages, but not their tolerogenic CD11c(-)CCR2(-)CX3CR1(-) counterparts, are expanded in inflammatory bowel disease. Mucosal Immunol. 2018, 11, 1114-1126. [CrossRef]

147. Dharmasiri, S.; Garrido-Martin, E.M.; Harris, R.J.; Bateman, A.C.; Collins, J.E.; Cummings, J.R.; Sanchez-Elsner, T. Intestinal Macrophages Are Involved in the Pathology of Both Ulcerative Colitis and Crohn Disease. Inflamm. Bowel Dis. 2021, 27, 1641-1652. [CrossRef]

148. Liu, J.; Geng, X.; Hou, J.; Wu, G. New insights into M1/M2 macrophages: Key modulators in cancer progression. Cancer Cell Int. 2021, 21, 389. [CrossRef] [PubMed]

149. Seyedizade, S.S.; Afshari, K.; Bayat, S.; Rahmani, F.; Momtaz, S.; Rezaei, N.; Abdolghaffari, A.H. Current Status of M1 and M2 Macrophages Pathway as Drug Targets for Inflammatory Bowel Disease. Arch. Immunol. Ther. Exp. 2020, 68, 10. [CrossRef]

150. Shin, S.H.; Kadayakkara, D.K.; Bulte, J.W. In Vivo (19)F MR Imaging Cell Tracking of Inflammatory Macrophages and Site-specific Development of Colitis-associated Dysplasia. Radiology 2017, 282, 194-201. [CrossRef] [PubMed] 
151. Khan, M.W.; Keshavarzian, A.; Gounaris, E.; Melson, J.E.; Cheon, E.C.; Blatner, N.R.; Chen, Z.E.; Tsai, F.-N.; Lee, G.; Ryu, S.H.; et al. $\mathrm{PI} 3 \mathrm{~K} / \mathrm{AKT}$ signaling is essential for communication between tissue-infiltrating mast cells, macrophages, and epithelial cells in colitis-induced cancer. Clin. Cancer Res. 2013, 19, 2342-2354. [CrossRef] [PubMed]

152. Wang, W.E.I.; Li, X.; Zheng, D.; Zhang, D.; Peng, X.; Zhang, X.; Ai, F.; Wang, X.; Ma, J.; Xiong, W.; et al. Dynamic changes and functions of macrophages and M1/M2 subpopulations during ulcerative colitis-associated carcinogenesis in an AOM/DSS mouse model. Mol. Med. Rep. 2015, 11, 2397-2406. [CrossRef]

153. Kvorjak, M.; Ahmed, Y.; Miller, M.L.; Sriram, R.; Coronnello, C.; Hashash, J.G.; Hartman, D.J.; Telmer, C.A.; Miskov-Zivanov, N.; Finn, O.J.; et al. Cross-talk between Colon Cells and Macrophages Increases ST6GALNAC1 and MUC1-sTn Expression in Ulcerative Colitis and Colitis-Associated Colon Cancer. Cancer Immunol. Res. 2020, 8, 167-178. [CrossRef]

154. Serbina, N.V.; Salazar-Mather, T.P.; Biron, C.A.; Kuziel, W.A.; Pamer, E.G. TNF/iNOS-producing dendritic cells mediate innate immune defense against bacterial infection. Immunity 2003, 19, 59-70. [CrossRef]

155. Moreira, T.G.; Horta, L.S.; Gomes-Santos, A.C.; Oliveira, R.P.; Queiroz, N.M.G.P.; Mangani, D.; Daniel, B.; Vieira, A.T.; Liu, S.; Rodrigues, A.M.; et al. CLA-supplemented diet accelerates experimental colorectal cancer by inducing TGF- $\beta$-producing macrophages and T cells. Mucosal Immunol. 2019, 12, 188-199. [CrossRef]

156. Wang, L.; Yu, S.; Chan, E.R.; Chen, K.-Y.; Liu, C.; Che, D.; Awadallah, A.; Myers, J.; Askew, D.; Huang, A.Y.; et al. Notch-Regulated Dendritic Cells Restrain Inflammation-Associated Colorectal Carcinogenesis. Cancer Immunol. Res. 2021, 9, 348-361. [CrossRef]

157. Hong, E.-H.; Cho, J.; Ahn, J.-H.; Kwon, B.-E.; Kweon, M.-N.; Seo, S.-U.; Yoon, B.-I.; Chang, S.-Y.; Ko, H.-J. Plasmacytoid dendritic cells regulate colitis-associated tumorigenesis by controlling myeloid-derived suppressor cell infiltration. Cancer Lett. 2020, 493, 102-112. [CrossRef] [PubMed]

158. Katoh, H.; Wang, D.; Daikoku, T.; Sun, H.; Dey, S.K.; Dubois, R.N. CXCR2-expressing myeloid-derived suppressor cells are essential to promote colitis-associated tumorigenesis. Cancer Cell 2013, 24, 631-644. [CrossRef] [PubMed]

159. Amy, I.Y.; Zhao, L.; Eaton, K.A.; Ho, S.; Chen, J.; Poe, S.; Becker, J.; Gonzalez, A.; McKinstry, D.; Hasso, M.; et al. Gut Microbiota Modulate CD8 T Cell Responses to Influence Colitis-Associated Tumorigenesis. Cell Rep. 2020, 31, 107471.

160. Yassin, M.; Sadowska, Z.; Djurhuus, D.; Nielsen, B.; Tougaard, P.; Olsen, J.; Pedersen, A.E. Upregulation of PD-1 follows tumour development in the AOM/DSS model of inflammation-induced colorectal cancer in mice. Immunology 2019, 158, 35-46. [CrossRef]

161. Michael-Robinson, J.; Pandeya, N.; Walsh, M.D.; Biemer-Huttmann, A.-E.; Eri, R.; Buttenshaw, R.; Lincoln, D.; Clouston, A.; Jass, J.; Radford-Smith, G. Characterization of tumour-infiltrating lymphocytes and apoptosis in colitis-associated neoplasia: Comparison with sporadic colorectal cancer. J. Pathol. 2006, 208, 381-387. [CrossRef]

162. Pastille, E.; Bardini, K.; Fleissner, D.; Adamczyk, A.; Frede, A.; Wadwa, M.; Von Smolinski, D.; Kasper, S.; Sparwasser, T.; Gruber, A.D.; et al. Transient ablation of regulatory T cells improves antitumor immunity in colitis-associated colon cancer. Cancer Res. 2014, 74, 4258-4269. [CrossRef] [PubMed]

163. Olguín, J.E.; Medina-Andrade, I.; Molina, E.; Vázquez, A.; Pacheco-Fernández, T.; Saavedra, R.; Perez-Plasencia, C.; Chirino, Y.I.; Vaca-Paniagua, F.; Arias-Romero, L.E.; et al. Early and Partial Reduction in CD4(+)Foxp3(+) Regulatory T Cells during Colitis-Associated Colon Cancer Induces CD4(+) and CD8(+) T Cell Activation Inhibiting Tumorigenesis. J. Cancer 2018, 9, 239-249. [CrossRef]

164. Zaiatz Bittencourt, V.; Jones, F.; Tosetto, M.; Doherty, G.A.; Ryan, E.J. Dysregulation of Metabolic Pathways in Circulating Natural Killer Cells Isolated from Inflammatory Bowel Disease Patients. J. Crohns Colitis. 2021, 15, 1316-1325. [CrossRef] [PubMed]

165. Therrien, A.; Chapuy, L.; Bsat, M.; Rubio, M.; Bernard, G.; Arslanian, E.; Orlicka, K.; Weber, A.; Panzini, B.; Dorais, J.; et al. Recruitment of activated neutrophils correlates with disease severity in adult Crohn's disease. Clin. Exp. Immunol. 2019, 195, 251-264. [CrossRef] [PubMed]

166. Alhmoud, T.; Gremida, A.; Steele, D.C.; Fallahi, I.; Tuqan, W.; Nandy, N.; Ismail, M.; Altamimi, B.A.; Xiong, M.-J.; Kerwin, A.; et al. Outcomes of inflammatory bowel disease in patients with eosinophil-predominant colonic inflammation. BMJ Open Gastroenterol. 2020, 7, e000373. [CrossRef]

167. Lin, Y.; Cheng, L.; Liu, Y.; Wang, Y.; Wang, Q.N.; Wang, H.L.; Shi, G.; Li, J.S.; Yang, Q.M.; Chen, S.; et al. Intestinal epitheliumderived BATF3 promotes colitis-associated colon cancer through facilitating CXCL5-mediated neutrophils recruitment. Mucosal Immunol. 2021, 14, 187-198. [CrossRef]

168. Wéra, O.; Lancellotti, P.; Oury, C. The Dual Role of Neutrophils in Inflammatory Bowel Diseases. J. Clin. Med. 2016, 5, 118. [CrossRef]

169. Knaapen, A.M.; Schins, R.P.; Polat, D.; Becker, A.; Borm, P.J. Mechanisms of neutrophil-induced DNA damage in respiratory tract epithelial cells. Mol. Cell Biochem. 2002, 234-235, 143-151. [CrossRef]

170. Zhou, G.; Peng, K.; Song, Y.; Yang, W.; Shu, W.; Yu, T.; Yu, L.; Lin, M.; Weigang, S.; Chen, C.; et al. CD177+ neutrophils suppress epithelial cell tumourigenesis in colitis-associated cancer and predict good prognosis in colorectal cancer. Carcinogenesis 2018, 39, 272-282. [CrossRef] [PubMed]

171. Triner, D.; Devenport, S.N.; Ramakrishnan, S.K.; Ma, X.; Frieler, R.A.; Greenson, J.K. Neutrophils Restrict Tumor-Associated Microbiota to Reduce Growth and Invasion of Colon Tumors in Mice. Gastroenterology 2019, 156, 1467-1482. [CrossRef]

172. Lampinen, M.; Backman, M.; Winqvist, O.; Rorsman, F.; Rönnblom, A.; Sangfelt, P.; Carlson, M. Different regulation of eosinophil activity in Crohn's disease compared with ulcerative colitis. J. Leukoc. Biol. 2008, 84, 1392-1399. [CrossRef]

173. Leoncini, G.; Villanacci, V.; Marin, M.G.; Crisafulli, V.; Cadei, M.; Antonelli, E.; Leoci, C.; Bassotti, G. Colonic hypereosinophilia in ulcerative colitis may help to predict the failure of steroid therapy. Tech. Coloproctol. 2018, 22, 941-946. [CrossRef] 
174. Sastre, B.; Rodrigo-Muñoz, J.M.; Garcia-Sanchez, D.A.; Cañas, J.A.; Del Pozo, V. Eosinophils: Old Players in a New Game. J. Investig. Allergol. Clin. Immunol. 2018, 28, 289-304. [CrossRef]

175. Hu, G.; Wang, S.; Zhong, K.; Xu, F.; Huang, L.; Chen, W.; Cheng, P. Tumor-associated tissue eosinophilia predicts favorable clinical outcome in solid tumors: A meta-analysis. BMC Cancer 2020, 20, 454. [CrossRef]

176. Moreira, A.; Leisgang, W.; Schuler, G.; Heinzerling, L. Eosinophilic count as a biomarker for prognosis of melanoma patients and its importance in the response to immunotherapy. Immunotherapy 2017, 9, 115-121. [CrossRef]

177. Harbaum, L.; Pollheimer, M.J.; Kornprat, P.; Lindtner, R.A.; Bokemeyer, C.; Langner, C. Peritumoral eosinophils predict recurrence in colorectal cancer. Mod. Pathol. 2015, 28, 403-413. [CrossRef] [PubMed]

178. Prizment, A.E.; Vierkant, R.; Smyrk, T.C.; Tillmans, L.S.; Lee, J.J.; Sriramarao, P.; Nelson, H.; Lynch, C.F.; Thibodeau, S.N.; Church, T.R.; et al. Tumor eosinophil infiltration and improved survival of colorectal cancer patients: Iowa Women's Health Study. Mod. Pathol. 2016, 29, 516-527. [CrossRef]

179. Kienzl, M.; Hasenoehrl, C.; Valadez-Cosmes, P.; Maitz, K.; Sarsembayeva, A.; Sturm, E.; Heinemann, A.; Kargl, J.; Schicho, R. IL-33 reduces tumor growth in models of colorectal cancer with the help of eosinophils. Oncoimmunology 2020, 9, 1776059. [CrossRef]

180. Jaensson, E.; Uronen-Hansson, H.; Pabst, O.; Eksteen, B.; Tian, J.; Coombes, J.L.; Berg, P.L.; Davidsson, T.; Powrie, F.; JohanssonLindbom, B.; et al. Small intestinal CD103+ dendritic cells display unique functional properties that are conserved between mice and humans. J. Exp. Med. 2008, 205, 2139-2149. [CrossRef] [PubMed]

181. Baumgart, D.C.; Thomas, S.; Przesdzing, I.; Metzke, D.; Bielecki, C.; Lehmann, S.M.; Lehnardt, S.; Dörffel, Y.; Sturm, A.; Scheffold, A.; et al. Exaggerated inflammatory response of primary human myeloid dendritic cells to lipopolysaccharide in patients with inflammatory bowel disease. Clin. Exp. Immunol. 2009, 157, 423-436. [CrossRef] [PubMed]

182. Bakdash, G.; Vogelpoel, L.T.; van Capel, T.M.; Kapsenberg, M.L.; de Jong, E.C. Retinoic acid primes human dendritic cells to induce gut-homing, IL-10-producing regulatory T cells. Mucosal Immunol. 2015, 8, 265-278. [CrossRef]

183. Matsuno, H.; Kayama, H.; Nishimura, J.; Sekido, Y.; Osawa, H.; Barman, S.; Ogino, T.; Takahashi, H.; Haraguchi, N.; Hata, T.; et al. CD103+ Dendritic Cell Function Is Altered in the Colons of Patients with Ulcerative Colitis. Inflamm. Bowel Dis. 2017, 23, 1524-1534. [CrossRef] [PubMed]

184. Pool, L. Intestinal Classical Dendritic in T Cell Induced Colitis and Colitis Associated Colorectal Cancer; DTU Nanotech, Technical University of Denmark: Lyngby, Denmark, 2018.

185. Garrett, W.S.; Punit, S.; Gallini, C.A.; Michaud, M.; Zhang, D.; Sigrist, K.S.; Lord, G.M.; Glickman, J.N.; Glimcher, L.H. Colitisassociated colorectal cancer driven by T-bet deficiency in dendritic cells. Cancer Cell 2009, 16, 208-219. [CrossRef]

186. Yang, Y.; Li, C.; Liu, T.; Dai, X.; Bazhin, A.V. Myeloid-Derived Suppressor Cells in Tumors: From Mechanisms to Antigen Specificity and Microenvironmental Regulation. Front. Immunol. 2020, 11, 1371. [CrossRef]

187. Groth, C.; Arpinati, L.; Shaul, M.; Winkler, N.; Diester, K.; Gengenbacher, N.; Weber, R.; Arkhypov, I.; Lasser, S.; Petrova, V.; et al. Blocking Migration of Polymorphonuclear Myeloid-Derived Suppressor Cells Inhibits Mouse Melanoma Progression. Cancers 2021, 13, 726. [CrossRef]

188. James, S.P.; Kwan, W.C.; Sneller, M.C. T cells in inductive and effector compartments of the intestinal mucosal immune system of nonhuman primates differ in lymphokine mRNA expression, lymphokine utilization, and regulatory function. J. Immunol. 1990, 144, 1251-1256. [PubMed]

189. Tindemans, I.; Joosse, M.E.; Samsom, J.N. Dissecting the Heterogeneity in T-Cell Mediated Inflammation in IBD. Cells 2020, 9 , 110. [CrossRef]

190. Okeke, E.B.; Uzonna, J.E. The Pivotal Role of Regulatory T Cells in the Regulation of Innate Immune Cells. Front. Immunol. 2019, 10, 680. [CrossRef] [PubMed]

191. Van Wijk, F.; Cheroutre, H. Mucosal T cells in gut homeostasis and inflammation. Expert Rev. Clin. Immunol. 2010, 6, 559-566. [CrossRef] [PubMed]

192. Geremia, A.; Biancheri, P.; Allan, P.; Corazza, G.R.; Di Sabatino, A. Innate and adaptive immunity in inflammatory bowel disease. Autoimmun. Rev. 2014, 13, 3-10. [CrossRef]

193. Ostroumov, D.; Fekete-Drimusz, N.; Saborowski, M.; Kühnel, F.; Woller, N. CD4 and CD8 T lymphocyte interplay in controlling tumor growth. Cell Mol. Life Sci. 2018, 75, 689-713. [CrossRef]

194. Scarpa, M.; Brun, P.; Scarpa, M.; Morgan, S.; Porzionato, A.; Kotsafti, A.; Bortolami, M.; Buda, A.; D’Incà, R.; Macchi, V.; et al. CD80-CD28 signaling controls the progression of inflammatory colorectal carcinogenesis. Oncotarget 2015, 6, 20058-20069. [CrossRef] [PubMed]

195. Tang, C.; Yamada, H.; Shibata, K.; Muta, H.; Wajjwalku, W.; Podack, E.R.; Yoshikai, Y. A novel role of CD30L/CD30 signaling by T-T cell interaction in Th1 response against mycobacterial infection. J. Immunol. 2008, 181, 6316-6327. [CrossRef]

196. Wang, X.; Gao, Y.; Zhang, X.; Wang, X.; Wang, B.; Meng, X.; Yoshikai, Y.; Wang, Y.; Sun, X. CD30L/CD30 signaling regulates the formation of the tumor immune microenvironment and inhibits intestinal tumor development of colitis-associated colon cancer in mice. Int. Immunopharmacol. 2020, 84, 106531. [CrossRef]

197. Catakovic, K.; Klieser, E.; Neureiter, D.; Geisberger, R. T cell exhaustion: From pathophysiological basics to tumor immunotherapy. Cell Commun. Signal. 2017, 15, 1. [CrossRef]

198. Ozawa, N.; Yokobori, T.; Osone, K.; Katayama, C.; Suga, K.; Komine, C.; Shibasaki, Y.; Shiraishi, T.; Okada, T.; Kato, R.; et al. PD-L1 upregulation is associated with activation of the DNA double-strand break repair pathway in patients with colitic cancer. Sci. Rep. 2021, 11, 13077. [CrossRef] 
199. Kryczek, I.; Wu, K.; Zhao, E.; Wei, S.; Vatan, L.; Szeliga, W.; Huang, E.; Greenson, J.; Chang, A.; Rolinski, J.M.; et al. IL-17+ regulatory $\mathrm{T}$ cells in the microenvironments of chronic inflammation and cancer. J. Immunol. 2011, 186, 4388-4395. [CrossRef] [PubMed]

200. Li, L.; Boussiotis, V.A. The role of IL-17-producing Foxp3+ CD4+ T cells in inflammatory bowel disease and colon cancer. Clin. Immunol. 2013, 148, 246-253. [CrossRef]

201. Ueno, A.; Jijon, H.; Chan, R.; Ford, K.; Hirota, C.; Kaplan, G.G.; Beck, P.L.; Iacucci, M.; Gasia, M.F.; Barkema, H.W.; et al. Increased prevalence of circulating novel IL-17 secreting Foxp3 expressing CD4+ T cells and defective suppressive function of circulating Foxp3+ regulatory cells support plasticity between Th17 and regulatory T cells in inflammatory bowel disease patients. Inflamm. Bowel Dis. 2013, 19, 2522-2534. [CrossRef] [PubMed]

202. Rizzo, A.; Di Giovangiulio, M.; Stolfi, C.; Franzè, E.; Fehling, H.-J.; Carsetti, R.; Giorda, E.; Colantoni, A.; Ortenzi, A.; Rugge, M.; et al. ROR $\gamma \mathrm{t}$-Expressing Tregs Drive the Growth of Colitis-Associated Colorectal Cancer by Controlling IL6 in Dendritic Cells. Cancer Immunol. Res. 2018, 6, 1082-1092. [CrossRef]

203. Saez, A.; Gomez-Bris, R.; Herrero-Fernandez, B.; Mingorance, C.; Rius, C.; Gonzalez-Granado, J.M. Innate Lymphoid Cells in Intestinal Homeostasis and Inflammatory Bowel Disease. Int. J. Mol. Sci. 2021, 22, 7618. [CrossRef] [PubMed]

204. Hosomi, S.; Grootjans, J.; Tschurtschenthaler, M.; Krupka, N.; Matute, J.D.; Flak, M.B.; Martinez-Naves, E.; Del Moral, M.G.; Glickman, J.N.; Ohira, M.; et al. Intestinal epithelial cell endoplasmic reticulum stress promotes MULT1 up-regulation and NKG2D-mediated inflammation. J. Exp. Med. 2017, 214, 2985-2997. [CrossRef]

205. Liu, Z.; Yang, L.; Cui, Y.; Wang, X.; Guo, C.; Huang, Z.; Kan, Q.; Liu, Z.; Liu, Y. Il-21 enhances NK cell activation and cytolytic activity and induces Th17 cell differentiation in inflammatory bowel disease. Inflamm. Bowel Dis. 2009, 15, 1133-1144. [CrossRef]

206. Waldhauer, I.; Steinle, A. NK cells and cancer immunosurveillance. Oncogene 2008, 27, 5932-5943. [CrossRef]

207. Wu, S.Y.; Fu, T.; Jiang, Y.Z.; Shao, Z.M. Natural killer cells in cancer biology and therapy. Mol. Cancer 2020, 19, 120. [CrossRef] [PubMed]

208. Bahri, R.; Pateras, I.S.; D’Orlando, O.; Goyeneche-Patino, D.A.; Campbell, M.; Polansky, J.K.; Sandig, H.; Papaioannou, M.; Evangelou, K.; Foukas, P.G.; et al. IL-15 suppresses colitis-associated colon carcinogenesis by inducing antitumor immunity. Oncoimmunology 2015, 4, e1002721. [CrossRef] [PubMed]

209. Kuen, D.S.; Kim, B.S.; Chung, Y. IL-17-Producing Cells in Tumor Immunity: Friends or Foes? Immune Netw. 2020, 20, e6. [CrossRef] [PubMed]

210. Yan, J.; Smyth, M.J.; Teng, M.W.L. Interleukin (IL)-12 and IL-23 and Their Conflicting Roles in Cancer. Cold Spring Harb Perspect Biol. 2018, 10, a028530. [CrossRef]

211. Eyerich, K.; Dimartino, V.; Cavani, A. IL-17 and IL-22 in immunity: Driving protection and pathology. Eur. J. Immunol. 2017, 47, 607-614. [CrossRef]

212. Kirchberger, S.; Royston, D.J.; Boulard, O.; Thornton, E.; Franchini, F.; Szabady, R.L.; Harrison, O.; Powrie, F. Innate lymphoid cells sustain colon cancer through production of interleukin-22 in a mouse model. J. Exp. Med. 2013, 210, 917-931. [CrossRef]

213. Tolomeo, M.; Cascio, A. The Multifaced Role of STAT3 in Cancer and Its Implication for Anticancer Therapy. Int. J. Mol. Sci. 2021, 22, 603. [CrossRef] 